University of Rhode Island

DigitalCommons@URI

Open Access Master's Theses

1997

\title{
PLANNING IN CONTROVERSY A CASE STUDY
}

Roseann Hegarty Cronan

University of Rhode Island

Follow this and additional works at: https://digitalcommons.uri.edu/theses

\section{Recommended Citation}

Cronan, Roseann Hegarty, "PLANNING IN CONTROVERSY A CASE STUDY" (1997). Open Access Master's Theses. Paper 580.

https://digitalcommons.uri.edu/theses/580

This Thesis is brought to you for free and open access by DigitalCommons@URI. It has been accepted for inclusion in Open Access Master's Theses by an authorized administrator of DigitalCommons@URI. For more information, please contact digitalcommons-group@uri.edu. 
PLANNING IN CONTROVERSY

A CASE STUDY

BY

ROSEANN HEGARTY CRONAN

A RESEARCH PROJECT SUBMITTED IN PARTIAL FULFILLMENT

OF THE REQUIREMENTS FOR THE DEGREE OF

MASTER OF COMMUNITY PLANNING

UNIVERSITY OF RHODE ISLAND

1997 


\section{MASTER OF COMMUNITY PLANNING}

RESEARCH PROJECT

OF

\section{ROSEANN HEGARTY CRONAN}

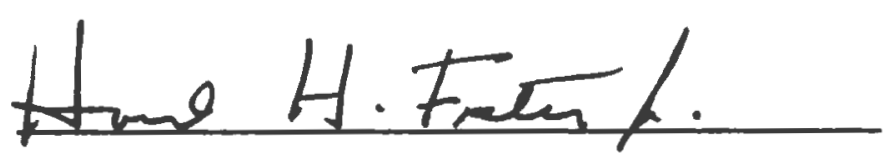

Approved: Major Professor Dr. Howard Foster

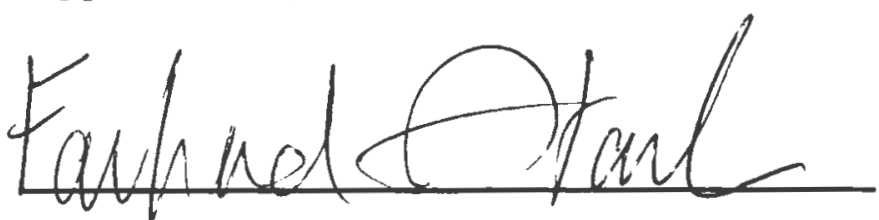

Acknowledged: Director Dr. Farhad Atash 


\begin{abstract}
Practicing planners are facing an increasing number of professional and ethical dilemmas in their professional lives. As public servants, both elected officials and professionals have been forced to become more responsive to the public demand and attitudes. As a result, many of the values influential in the past have been reassessed (Thomas, 1991).
\end{abstract}

On August 29, 1994, the governor of the state of Rhode Island and Providence Plantations announced a compact for an Indian sponsored gambling casino in the town of West Greenwich, Rhode Island. The compact was subject to both local and statewide approval. The referendum would take place nine weeks from the date of the announced proposal. Citizen reaction was immediate, passionate, and divided. The issue of gaming was complex; the sense of urgency was conspicuous; and tensions were apparent between multiple interest groups and stakeholders. Proponents of the casino guaranteed a jackpot of local job opportunities and wind fall tax revenues. Opponents feared grave disruption of social, environmental, and economic consequences. Local residents looked to town leaders for information on how the town would be impacted from the proposal.

This case example is an empirical inquiry which examines a contemporary phenomena within a real-life context. Illustrative of the case study, this inquiry examines how and why the writer/planner intervened in a highly acclaimed, politically charged public policy issue. Subjects discussed include circumstances, principles, value commitments, and personal characteristics that influenced the behavior of the writer/planner. At the heart of the study is an assessment of the role of the town planner. 


\section{Acknowledgments}

For assistance in developing this topic, I would like to thank Dr. Howard Foster for his sound advice; his tremendous patience with my deadlines; and his thoughtful encouragement while completing this project. Additionally, my appreciation to Dr. Marcia Feld for her reflective insight and guidance. Her comments were timely and reassuring.

Throughout this challenging project, my sincere gratitude to the support of my family: To my parents, who demonstrated values which I strive to model for my children. To my husband, for unyielding support and confidence; and to my loving, patient children, you are all a tremendous inspiration and source of joy to me. 


\section{PREFACE}

\section{Problem Statement}

Recent discussion about planning practice has been highlighted by the evolution in the way that planners have seen themselves: as architects, designers, engineers, social engineers, and most recently as political actors who bargain and negotiate. More recently post modern planner's role place emphasis on the planner as more than a technical advisor to bureaucrats. Planners are called upon to inform, influence, encourage, speak about, and take an active role in the setting of public policy. They are more active participants in the articulation of and movement toward what is thought (by whom), to be beneficial and valuable to the planner's client community. This activity is forcing planners to take a closer look at the ethical and moral dimensions of their practice (Kaufman, 1981).

\section{Practical Suggestions For Planning}

The analysis of decision making processes and role choices, relative to professional and ethical concerns, are planning concepts that deserve careful examination by planner's in every facet of theory and practice. These normative concepts in contemporary settings are susceptible to theoretical scrutiny and have practical implications. In positioning for and managing controversial situations, ambiguity and discretion in planners' roles have been the topic of professional discussion in the past. However, recent research is calling for a closer look at why these difficult situations occur and how to handle the dilemmas they present (Thomas, 1991 and Feld, 1989). 


\section{Case Example As Context of Analysis of Planner's Role}

It is clear that town planners as an occupational group, have little basis for claims to professional autonomy. They have some discretion to put forward their own professional concepts in planning, but the use made of these ideas in practice depends on the control of the profession by other interests. Planners in local government have to rely on the legitimization of their ideas, both through the statutory system and through the local political system. There can be tension between state or federal and local government perceptions. and between each; and the expectations of the various groups which comprise the "public". Planners are called on to mediate these tensions, but the outcome depends on the planner's position in relation to the balance of power between the different interests.

\section{Nature and Scope of Project}

This inquiry explores theoretical perspectives on influences that play a part in shaping the role of professional planning and the work of the contemporary practicing planners. The goal of this study is to add to the discussion of how planners deal with controversial situations. The objective is to provide first hand information about how the writer/planner managed professional and ethical concerns which occurred during the nine week time of study. More specifically, in the context of perceived controversy, how did writer/planner perceive issues; articulate concerns; and chose action to address the issues of concern; with whom; and with what consequences. 


\section{PROJECT OVERVIEW}

The topics for discussion throughout this project are focused on the broad topics of the role of the planner; the profession of planning; and some of the many questions posed by current research on the influences which shape the role of the practicing planner. What can be learned about the influences which shaped the role, and impacted the behavior of the writer/planner? What happens when professional ideas about public policy clash with others? The case example explores scholarly theories to these and others questions. The purpose of this qualitative research study is to better understand the professional planning process and dynamics which were set in motion during the time of study. The project will be presented in the following chapters:

\section{Chapter One: Literature Review}

This chapter briefly discusses the evolution of planning thought: the ongoing tension between the role of the planner as value neutral technical advisor and the more politically influential role of the planner as an active participant in the planning process: and, how this role orientation can be problematic in contemporary planning practice. The more politically active contemporary planners behave in their professional activity, the more likely they are to confront dilemmas concerning their response. The next questions are how to deal with these uncertain circumstances; and what influences play a part in shaping the profession, as well as the planner? In describing the case example, the references establish a theoretical framework within which context the assessment of the 
characteristics which influence the behavior, and shape the role of the practicing planner in situations with professional and ethical concerns are explored.

\section{Chapter Two: Theoretical Framework}

This qualitative case study (Yin, 1989) is an empirical inquiry that examines a contemporary phenomena in a practical situation. This project method assigns value to the relationships between the professional planner, elected officials, and local residents. The theoretical models utilized for analysis emphasize those relationships and will assess various activities and professional role orientation during the time of study. More specifically, this section will construct the schema for the description of the professional planning process, and writer/planner's actions in terms of: (a) observable aspects which include activities and visible behavior; and, (b) unobservable aspects which include values, thoughts and feelings. The outcomes of this project include linking the observable actions that defined the role of the writer/planner with the less perceptible personal characteristics which shaped decisions to act.

\section{Chapter Three: Case Example}

This portion of the report is a narrative retrospective of chronology of events during the nine week time of study. As participant-observer (Babbie, 1992 and Yin, 1989), the writer/planner assembled primary data that were originally recorded from personal copies of a planning office telephone log book; daily planning journal and calendar; meeting and conversation notes; as well as summaries of interviews and site visits. Narrative rhetoric is used as an effective means of conveying the integrated details of the context. participants, conditions, events, and actions in an overall recounting of this case example. 


\section{Chapter Four: Findings}

This chapter relates the rationale for particular activities undertaken by the writer/planner

in this case example to the theoretical framework. As an empirical study (Yin, 1989) on behavior, the findings will discuss the types of planning related activities (observable) that defined the role of the writer/planner as experienced in the case example.

\section{Chapter Five: Conclusions - A Planners Perspective}

Conclusions will discuss the (unobservable) aspects which shaped writer/planner's decisions to act. More precisely, this section represents a personal account of the writer/planner's reflection and will further relate the steps outlined in the theoretical framework to articulate and explain the thoughts, feelings, wishes, value commitments, and personal characteristics which contributed to the "whole role" (Baum, 1988), as experienced in the case example. 


\section{Table of Contents}

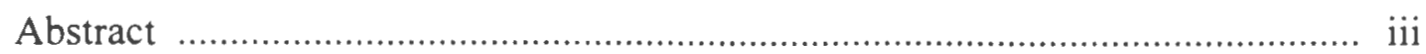

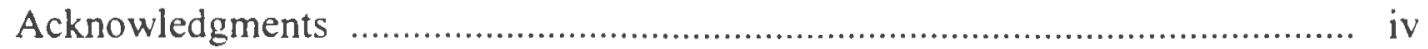

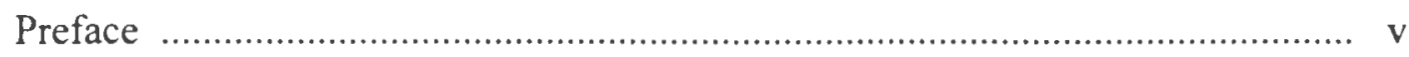

Project Overview ...................................................................................... vii

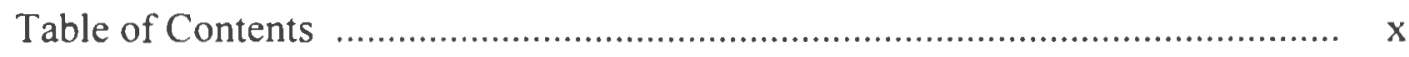

List of Tables

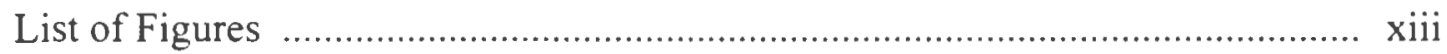

CHAPTER ONE:

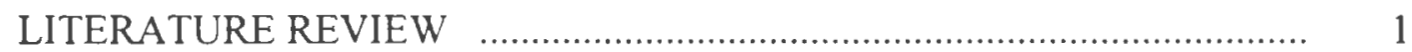

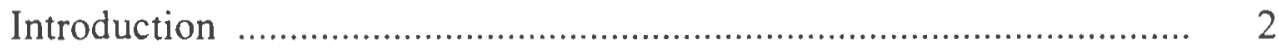

I. Popular Perspectives of Traditional Planning Theory .................... 2

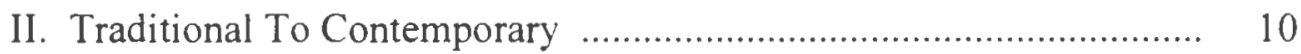

III. Practical Problems In Contemporary Planning and Why $\ldots \ldots \ldots \ldots . . . . . . . \quad 12$

IV. How To Prepare For Difficult Planning Situations f...................... 15

V. What Now? Next Steps f...................................................... 19

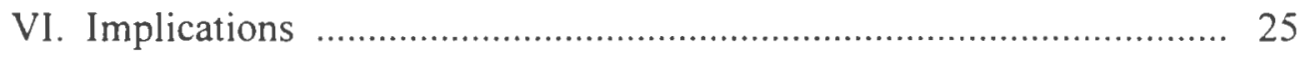

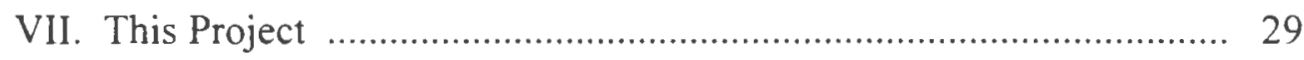

CHAPTER TWO:

THEORETICAL FRAMEWORK …................................................... 32

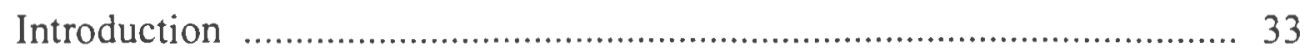

Step One: Contextual Characteristics …...................................... 36 
Step Two: Assessing Ethical Behavior ……………............................ 37

Step Three: Examination of Personal Characteristics .............................. 42

CHAPTER THREE:

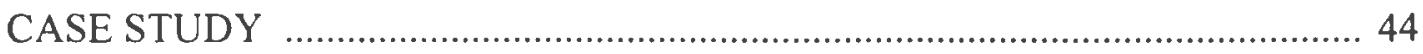

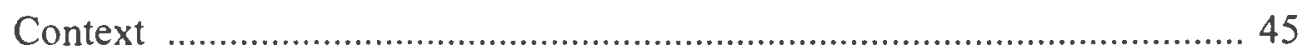

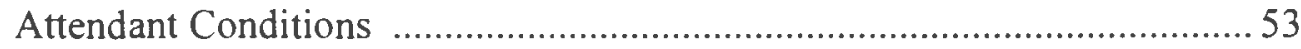

Nature of Substantive Issue ............................................................... 55

The Outlook On Gambling In West Greenwich, As Perceived by

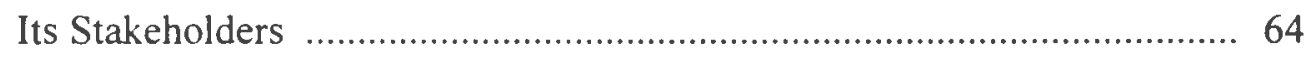

Chronology Of Events …….............................................................. 71

CHAPTER FOUR: FINDINGS ................................................................. 91

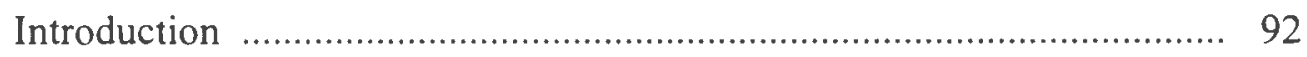

Ethical Concerns and Issues Benefiting ............................................... 93

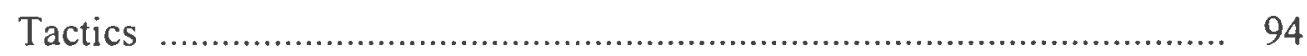

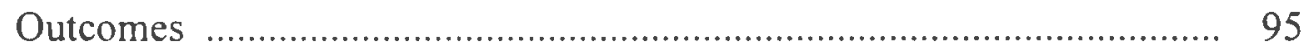

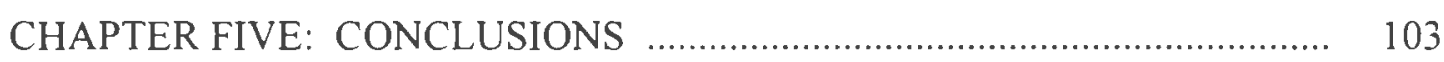

Influences On Planners Behavior ………............................................. 104

Dependent Variables And The Role Of Planners …………………........ 105

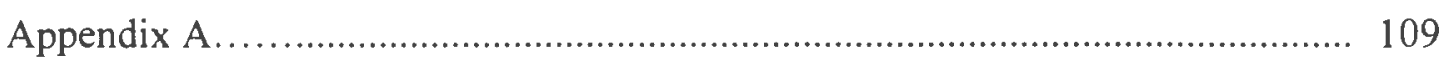

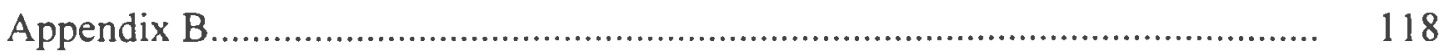

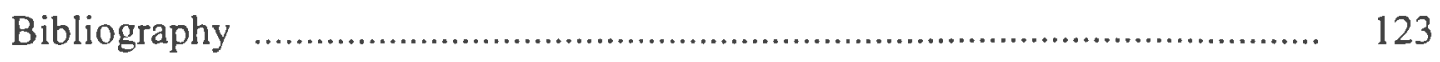




\section{List of Tables}

Table 1: $\quad$ Professional Planning Activities and Ethical Concerns

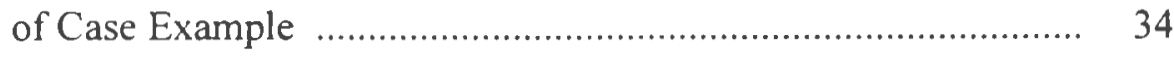

Table 2: $\quad$ Analysis of West Greenwich Gambling Casino Proposal .............. 57

Table 3: Professional Planning Activities and Subsequent Details ............. 93

Table 4: Who Writer/Planner Conferred With To Resolve Issues ............... 97

Table 5: A Framework For Describing Ethical Issues ................................. 98

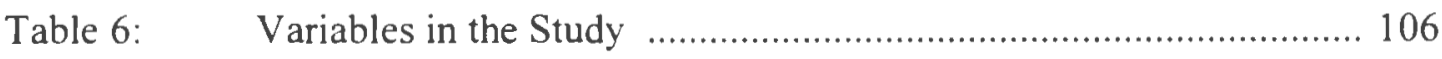




\section{$\underline{\text { List of Figures }}$}

Figure 1: $\quad$ West Greenwich Road Map ............................................... 47

Figure 2: $\quad$ West Greenwich Land Use Map ........................................... 49

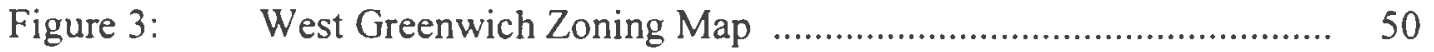

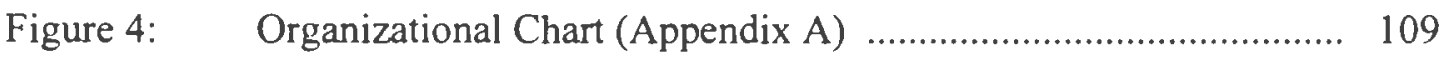

Figure 5: $\quad$ Summary Comments of Governor Sundlun

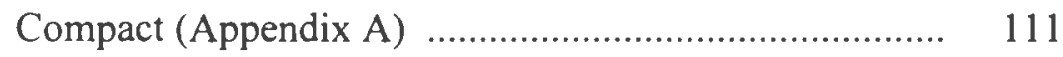




\section{CHAPTER ONE: LITERATURE REVIEW}

Planning is a normative endeavor entailing choices between alternative courses of action and sets of foreseen outcomes. Associated with these choices are ethical issues. At a time when more emphasis is being given to ethics in society in general and to ethics in professions in particular, it is important to know what planners believe to be the ethical underpinnings of their practice and where these positions come from (Hendler, 1991). 


\section{Introduction}

Selected references from the planning theory literature focuses on how and why planners chose action in controversial situations identified as posing dilemmas. This chapter will summarize current writings. First, an examination of the literature will explore popular theoretical perspectives that reflect the influences that informed planning practice in the past. Next is a discussion of the practical situations, such as professional and ethical dilemmas which planners are currently facing, and explanations as to why these phenomena are occurring. Third is an examination of recurring questions of "what now" in planning theory and prescriptions about future research. And last, a consideration of the implications in the literature for individual planners and the planning profession is reviewed. This chapter concludes with a statement of the project organization and how this empirical study is justified in the context of current literature.

\section{POPULAR PERSPECTIVES OF PLANNING THEORY}

In order to better appreciate the evolution of planning thought that addresses the topics of this section; it is appropriate to review the content of earlier debates about planning and the historical dynamics of the role of planners in practice. Below is a summary of the most popular theories on traditional roles:

\section{Traditional Theory}

The first role model to be discussed, was the dominant model for planners during the 1950s and early 60s. According to Huw Thomas (1991), the primary tasks of planning centered around urban building and rebuilding; skills required were those associated with 
existing professions. Planning problems were focused on uncontrolled urban growth, poor sanitation, transportation and public services. He goes on to say that early methodologies were straight-forward applications of the "design standards" approach of the more established professions such as engineering, architecture, and public health. Many writers see these as the substantive components of the planning process. Social reforms led the way to new models after the urban renewal developments of the $1960 \mathrm{~s}$ gave rise to disruptions of city plans.

Donald Schon(1982) writes that the traditional view of planning knowledge, often presented without differentiation as a view of what planners do and ought to know, is the doctrine of technical rationality. According to this view, planning is an instrumental adjustment of means to ends. The planner's task in any situation is, first, to set out the purposes to be achieved and the measures of their achievement. The purposes themselves

are usually assumed to be given by the client. by established policy, by an interrogation of social preferences, or by the political process. The planner must then identify the various possible means available to determine the relevant consequences likely to result from their pursuit, and select the course of action likely to achieve the desired purposes at minimum cost .

\section{The Dynamic History of Planners Knowledge}

Schon goes on to say that with the development of the city planning movement in the early years of this century, planners first gained visibility, power, and professional status. Following World War II, probably as a result of military and economic planning in wartime America. the idea of central planning extended its scope from comprehensive 
and master planning for towns to such fields as urban renewal, urban and regional transportation, health services, public education, mental health, and criminal justice. In these domains, among many others, the centralist planner operated from the base of institutions created and legitimized through legislation brought into being by a coalition of political forces. The planner framed his role at the center of a system for which he planned, in relation to agencies which would implement his plans and clienteles who would benefit from them. His system of knowledge-in-practice dealt with the framing of objectives and goals, the imaging of a desirable future, the description of baseline conditions, the identification of alternative strategies of action, the description of constraints to be circumvented or removed, the mapping of the system to be influenced, and the prediction of the consequences of action. Later, planners also came to be concerned with the feasibility of implementing plans and the political problems of "selling" them.

\section{Expansion of Planners Roles}

As notions of a growing pluralist society. with conflicts of interest, both between groups in society and consequently, between politicians and experts, thoughts about the relationships between politicians and experts in making public decisions emerged. Focus was centered on the planner's role, tasks, and the planning process. Notions of identifying multiple clients emerged as planners dealt with complex urban development. 


\section{Advocacy Planning - A Call to be More Active}

Pierre Clavel (1994) writes about the work of Paul Davidoff in the 1960s and 1970s and the tradition associated with advocacy planners and how their work evolved and was a bridge from an earlier, more monolithic culture to what may now emerge as a different and more diverse one. Advocacy planning began in response to political practices that combined a superficial pluralism with the effective exclusion of the poor and minorities, and also in response to a professional culture that was monolithic in its devotion to the physical plan, the independent planning commission and a not easily accessible public

interest. An essentially assimilationist view prevailed, that cities develop toward a single model, the melting pot of ethnicity's believed to produce a homogeneous "American" culture.

Barry Checkoway (1994) writes that Davidoff was an unyielding force for justice and equity in planning. Before his death in 1984. Davidoff made major contributions as a practitioner, educator, and intellectual whose writings have lasting significance for planning thought and action. Davidoff viewed planning as a process to address a wide range of societal problems; to improve conditions for all people while emphasizing resources and opportunities for those lacking in both: and to expand representation and participation of traditionally excluded groups in the decisions that affect their lives. He challenged planners to promote participatory democracy and positive social change; to overcome poverty and racism as factors in society; and to reduce disparities between rich and poor. 


\section{Identifying The Client}

Davidoff (1970) speaks of two general classes: the immediate client, or the planner's employer, and the ultimate clients, those citizens affected by the planning proposals. The planner must therefore take a preliminary step: the identification of his clients. Often terms of employment prescribe the reference group for the planner's activity. But in public planning with intervening administrative and legislative levels, the ability to easily to identify clients is a difficult task and often sidestepped.

Notions of tensions between distinguishing the immediate and ultimate client were highlighted by Herbert Gans (1991) who viewed the planner not as a reformer nor as a professional who is free to impose her/his expertise and values on the people for whom s/he plans, but as a public official. As such, s/he ought rather to be the public servant. helping citizens solve their problems and achieve their goals, except when these goals have antisocial and self-destructive consequences. In this process, the planner ought to propose a variety of programs to solve problems and achieve goals so that people have maximum choice. When determining the public interest in a heterogeneous population is difficult, this planning model proposes the allocation of resources so that the maximum benefits accrue to all, interest groups and communities the planner feels are in the greatest need of public benefits. Gans argues that the rational model which serves multiple groups can be found in democratic theory and principles of social justice. His approach to planning practice was exemplified in the work of the Cleveland City Planning commission and its chief planner of the 1970s. Norman Krumholz. 
During the 1970s Norman Krumholz (1982) believed the victims of the urban crisis were primarily the poor and working class residents of central cities. Krumholz said to solve urban problems planners must give priority to their needs, perhaps at the expense of other groups needs. This, however, means abandoning one of the planning profession's most cherished myths--that the planner is an apolitical technician, promoting goals that are widely accepted through the use of professional standards that are objectively correct. This fanciful notion has helped planners justify highway construction, urban renewal projects, and other public actions that have devastated poor and working class neighborhoods and have left central cities in worse condition.

\section{Beyond Land Use Planning}

Later, Krumholz (1994) writes that Davidoff's influential article "Advocacy and Pluralism in Planning" challenged ideas with more power and clarity than had been seen up to that time. Krumholz says he was impacted by the challenge to a number of beliefs that were widely accepted in the planning profession during the 1960s. Among them were the notions that city planning was apolitical and, instead of serving a narrow political objective, served the public interest; a unitary plan prepared by a public agency was adequate to express the interests of the entire community: and city planning was the planning of land uses which, if artfully done, with attention to greenspace and the close proximity of linked activities, would improve the quality of city life. Davidoff, ever the champion of justice and equity in planning, offered practitioners a way to broaden the 
area of concern beyond purely physical planning and showed that city planning was inevitably a method of policy selection that was firmly imbedded in the political process.

\section{Challenging Theories of Situational Expectations}

Baum (1988) In his work "Why Do Planners Do What They Do? The Little We Know and The Lot We Don't" (1988) says traditional planning theorists have emphasized one type of model: the expectation that planners collect and analyze abstract information about problems and goals, and that planners should respond to situations without considering either political interests or personal values. He writes that traditional theorists assume that "situations" are readily defined, and not ambiguous, so that it is self evident what an intelligent response should be. They tend to overlook, unlike the more recent writers on activist participation of planners in the planning process, the ways planners can shape public definitions of situations. He suggests that most current research concentrates on political situations and pays less attention to analytic situations. An implicit, even if unintended, normative message of this focus is a dichotomy: planners should emphasize political outcomes rather than "scientific" data analysis. An implicit empirical statement is that analysis will not significantly impact reductions of interested political stakeholders.

Schon (1982) writes that by the mid-sixties, the public at large. and planners themselves. were becoming increasingly aware of the counterintuitive consequences, the harmful side effects, and the unwanted by-products of implemented plans. Plans designed to solve problems failed to solve them, or created problems worse that the problems they had been designed to solve. Some of the phenomena planners were most anxious to influence -- 
poverty. crime, urban congestion, and decay--seemed tenaciously resistant to intervention.

Planners were found sometimes deliberately, sometimes unintentionally to be serving interests incongruent with their espoused values. Social critics, and also angry political constituencies, demonstrated that plans had meaning and consequence in areas well beyond the scope envisaged by planners. As the scope and complexity of planning increased, planners found that available techniques and models were inadequate to the tasks of analysis, diagnosis, and prediction. As planning issues became increasingly controversial, planning problems came to be seen more like dilemmas, involving conflicting values, interests, and ideologies whose resolution seemed not to be amenable to empirical inquiry.

\section{Planners and Power}

Increasingly, in the 1970s and early 1980s, planning theorists focused attention on the practical evidence that planning work was not undertaken solely in a technical mode, but in a more interactive fashion in a process with multiple and often competing interests. In his article on planner's use of information, John Forester (1982). writes that if planners ignore those in power, they assure their own powerlessness. Alternatively, if planners understand how relations of power work to structure the planning process, they can improve the quality of their analyses and empower citizen and community action as well. Planners in may areas are legally mandated to make democratic citizen participation in the planning process a reality rather that a romantic promise. However, planners often have had little influence upon the implementation of the plans that they produced. Those painstaking plans have too often ended on the shelf or have been used to further political purposes that were never intended to serve. Given these conditions of work and the 
political setting of planning practice, how then can planners work to fulfill their legal mandates to foster a genuinely democratic planning process? What power may planners have? In a time of retrenchment, these questions become more, and not less important than ever.

\section{TRADITIONAL TO CONTEMPORARY}

\section{Planning Models Not Adequate for Complex Society}

Klosterman (1981) describes how the last two decades in planning ideology and education have increasingly emphasized the planner's role as an applied scientist. The simplistic assumptions of the early profession have been replaced by an increased reliance on the theories and models of the social sciences. Aspects of contemporary planning education reflect this conception of the planner-as-scientist in its emphasis on statistics, planning methods and substantive theories of economics, sociology, regional science, and on the positive social sciences. He goes on to say that traditional approaches have been supplemented by proposals for advocacy planning in which planners promote the interests of community groups and for limiting planning's role to providing information to existing multi-centered policy-making processes. However, Klosterman argues that neither of these approaches eliminates the need for planner to deal with substantive ethical issues, and advocate planners must select the interests which are and are not to be represented in the planning process. Policy-making processes require a determination of (among other things) which studies are to be conducted, which data collected, and what findings provided to which community groups. Since the answers given to each of these questions affect the final policy which is adopted, they necessarily involve substantive ethical issues which must be resolved (either explicitly or implicitly) by planners. 


\section{More controversy and Problematic Role For Planners}

Schonn (1982) writes that the institutional context of practice is notoriously unstable, and there are many contending views of the profession, each of which carries a different image of the planning role and a different picture of the body of useful knowledge. Presently, for example, planners function variously as designer, plan makers, critics, advocates of special interest, regulators, managers, evaluators, and intermediaries. In planning as in other professions, each role tends to be associated with characteristic values, strategies, techniques, and bodies of relevant information. In the planning profession, however, images of role have evolved significantly in relatively brief periods of time. The profession, which came into being around the turn of the century moved in succeeding decades through different ideas in good currency about planning theory and practice, partly in response to changes in context shaped by planners themselves. The history of the evolution of planning roles can be understood as a global conversation between the planning profession and its situation.

\section{Role Choices for Planners}

According to Jerome Kaufman (1981), among the numerous historical ways that planners have seen themselves -- as architects, designers, engineers, social engineers, and most recently. political actors--, recent images have stressed that the planner is something more than a bureaucrat as technical functionary. Planners create, influence. speak about, encourage. stimulate, or otherwise take part in the setting of public policy. They do more than passively carry out the decisions and goals of others. They are active participants in 
the articulation of and movement toward that which is thought to be the public good, beneficial, and valuable for the planner's client community and its citizens.

\section{PRACTICAL PROBLEMS IN CONTEMPORARY PLANNING AND WHY}

Learning on the job can be problematic for many contemporary planners. It is important to build skills and acquire knowledge through experience and over time. The reality of this is that may planners are experiencing situations that present difficult choices on how to respond as a professional. As a result, according to Healy (in Thmas, 1991), planners must constantly reassess their position on any issue-is it legitimate in terms of their role as an effective planner. can it be justifies, it rational, fair, equitable and why?

\section{Normative Influence}

Many of the writers about planning ethics refer to the normative foundations of planning. For example Richard Klosterman (1976) writes the planning profession in the United States grew out of and has been in large part shaped by two very important intellectual traditions. First is the widespread Western Civilization faith in rationality and science which has viewed planning as the institutionalized application of the methods and findings of science to social affairs. Second in the United States. has been the great tradition of middle-class reform which uses planning as a means for improving government.

According to Hendler (1991), planning is a moral endeavor in which planners must make ethical choices. Associated with these choices are ethical issues, which range from procedural questions such as conflict of interest to substantive questions such as whether 
planners should advocate the rights of minority groups. These and related issues require planner to make decisions that conform, implicitly or explicitly, to established perspectives of what constitutes ethical behavior. An enhanced role of ethics in planning curricula and professional practice should focus attention on the substantive moral content inherent to the field. What sort of substantive values should planners have, and should planning professionals be autonomous problem -solvers or should they conform only to the expectations of an employer? It is often difficult to find explicit mention of substantive values in planning, however a place to start is the planning organization's code of professional ethics and conduct. The American Institute of Certified Planners contains principles regarding the natural and built environments, disadvantaged groups, and the importance of ethics. However, this code and that of the American Planning Association, have been criticized as being insubstantial and vague.

\section{Discretion and Planning Decisions}

According to Wachs (1984) planners face possible conflicts of interest and ambiguities regarding their responsibilities to the public. Planners exercise judgement on behalf of

the public. Approval of building plans, determination of the line and grade of a highway, and the choice of location for a sewage treatment plant are just a few examples of planners' decisions which affect the public welfare and deliver gains and losses to individual citizens. Through decisions of this type, planners participate directly in the governance of society: while laws enacted by elected representatives set down basic parameters, they generally leave much unspecified. 
Healy (in Thomas, 1991) goes on to say that planners have wide discretion when making decisions about the nature and scope of their services. Planners have both responsibility and discretion as professionals, yet in a democratic society, they are rarely directly responsible to the electorate. Planners share with other bureaucrats and professionals a responsibility for shaping the physical and institutional environments within which citizens live. Planners are however, removed from the direct accountability which binds elected officials to the citizenry and should therefore, examine the special responsibilities and ethical dilemmas posed by their administrative discretion.

Elizabeth Howe (1994) agrees with this perspective, and suggests that planners have available to them three rather different images of the purpose and role of the profession. The first emphasizes indirect responsibility to the public through loyal service to elected officials. A second has seen the planner as a more politically active and autonomous actor in the planning process. The third has stressed the role of the planner as a facilitator of the planning process. While the roles actually played out by the planners is more diverse than these three models, most contemporary planners draw from one or another as a starting place. Each of these roles provides a different answer to the central ethical question of the relationship between the expert planner, elected officials, and the public at large. Indeed, each role is associated with a distinctively different approach to ethics and practice. Planners in the first model see themselves as a loyal servant of elected officials are often content to leave the definition of goals to the decision makers. Their views of ethics focuses substantially on procedural actions that they judge to be right or wrong in 
themselves. Planners in the second model see themselves as more active, independent actors and are much more likely to be motivated by a strong commitment to a particular concept of "the good", or the public interest, which they strive to realize through the planning process. Although they often work to increase their own autonomy while still recognizing the legitimate primacy of elected officials, they do no automatically defer to them (Howe, 1994). In the third model, planners who see themselves as facilitators of the planning process are centrally concerned with fairness and the openness of that process. They see their role in relation to other actors as somewhat independent but responsive, bringing groups together to work out solutions to conflicts.

\section{HOW TO PREPARE FOR DIFFICULT PLANNING SITUATIONS}

Increased awareness of practical dilemmas has sharpened the focus on why situations presenting dilemmas are occurring and how to better prepare and respond.

Howe and Kaufman (1981) maintain that the difficulties of practicing for contemporary planners stems from the theoretical prescriptions of role models which are either so broadly defined that they can be variously interpreted or the "norms" may conflict with others' view. Partly because of such conflict and ambiguity, all planners may not reach the same conclusion about what is appropriate or inappropriate response to similar situations.

In the final analysis however the planner does not have the last word in the outcomes of their actions. Howe (1994) argues that planners do not serve private citizens but provide policy advice and administer support to public officials who retain control over the public 
bureaucracies in which they work. Planners are not ciphers. They do have discretion in the way they develop and give policy advice and in the way they implement planning procedures. The opportunity for independent action will vary depending on the given situation including the planner, the decision makers, the agency, and the larger political environment, but presenting policy advice and implementing plans always allows some room for independent judgment and action.

\section{Current Value Commitments}

In discussing the topic of roles and their influences, Howe and Kaufman (1981), state that a possible explanation for differences in perceptions among planners could be traced to a central and continuing conflict in planning: how can planners maintain their technical integrity, yet at the same time. be politically effective? Planning has been struggling over the question of its proper stance as a public profession in a democratic society. The issue has often been posed as a choice between the polar models of the planner as technician and the planner as a political actor. The former is defined as technically expert. value neutral, and responsible to the public through the political decision-makers s/he serves. But s/he is also dependent on those same political decision-makers for the implementation of "good" advice and plans. The latter, as an ideal type, is overtly value committed, perceived as more responsive to the community groups or issues s/he thinks are particularly related to the public interest, and more open to work actively through the political system to implement the plans. Only in recent years have there been attempts to think in terms of a role which combines aspects of both technical and political roles to achieve both integrity and effectiveness. 


\section{What Is Happening Now}

Some of the more recent studies (Howe, 1994 and Healy, 1991) reflect the current feeling among practicing planners as to the ambiguous nature of their roles in the planning process. Planners do have their own independent, professional ideas of good policy, which can be quite different from those held by the decision makers or the public at large (Howe, 1994). Therefore, what is happening now is that discretion and ambiguity lead to dilemmas in practice when planner's professional values clash with other stakeholders. Examining the practicing planners behavior and choice of roles is an important topic for current planning research.

Klosterman (as cited in Wachs, 1985) argues that along with the increased theoretical and methodological sophistication in planning practice, such as computer-assisted techniques and simulation models. linear programming, and regression analysis, has come a neglect of the profession's reform heritage. Implicit in the emphasis on analytic techniques and social science theory is a view of the planner as a "value-free technician" who collects and analyzes "factual" data concerning the means for achieving public policy objectives but avoids the "value" questions of defining these objectives which is carried out by the political process.

Wachs (1989) writes that planners do a great deal of analysis. They rely increasingly on data banks, statistical methods, mathematical models and computers. Planning schools must teach quantitative methods to qualify for accreditation. While not every planner employs every method, analytical techniques in common use include cohort-survival 
population forecasting, benefit-cost analysis, input-output analysis, traffic impact studies, housing market studies and many more. Planners also do surveys, construct data bases using survey results, and employ such complex technical databases as land-use information systems. To the extent that planners are successful in influencing the policies and actions of government, they are acting politically, in the most fundamental sense of the word, because their actions determine "who gets what, when, and how". As a result, their decisions and actions necessarily involve ethical concerns such as balancing the conflicting interest of the members of society. He states that it seems impossible both in practice and in principle to limit planning to only the factual considerations of means. Planners need not, in fact, cannot separate planning analysis from planning values by focusing only on technical questions of public policy.

He argues that planners are trapped between competing models of their role as scientists who analyze data to discover the truth and to arrive at the best course of action; or advocates who use data and models to prove that a course of action preferred by a client or employer is the best choice in a given situation. He proposes planners can go further and combine their dual commitment of scientific analysis and social reform in the rational consideration of the difficult but important question of defining public policy objectives. If this does happen and the rational evaluation and justification of public policy values joins the scientific analysis of public policy means as a guiding ideal of the profession. the implication for both theory and practice is far reaching. However, Baum (1988) discounts this approach to examining the history of planning thought. He writes that much of the current empirical study of planners focuses too much attention on political questions. In particular, researchers want to know whether planners 
recognize the interests implicated in issues, what values they bring to situations, and whether planners have strategic skills for dealing with involved parties. This interest forwards both an intellectual and political agenda. It is an intellectual reaction to traditional theory and its description of planning as analysis, with the implication that political involvement is not planning. It is a political reaction to the complaints of some planners and community groups of having little influence over planning and development decisions. The contemporary researchers seek to show that planners are always involved because of the nature of the planning process and that deliberate efforts by planners to act politically are necessary for serving rationality and equity.

\section{WHAT NOW? NEXT STEPS}

What Now? Perspectives on What Should and Do Influence Planning Practice.

There is an abundance of planning literature that focuses on the influences on role of the planner within the planning process. References used in this section draw substantially on theoretical perspectives that explore a particular theme arising from the question of what influences (or should influence) the planning profession and the role of the individual practicing planner. Each discussion looks at how the writer approaches the concepts associated with what specific element(s) influence planning practice and why it is relevant to this research project.

Practicing planners draw on a variety of resources, both professionally and personally, to make decision in their work lives where a clear path is not always evident. According to Howe (1994) ambiguity and discretion are indicators of the somewhat problematic status of planner's role within and outside the realms of professional planning. When 
professional ideas conflict with those of others, what influences the role choices of planners. More specifically, when practical experience presents dilemmas, how do practicing planners express their professional commitments, both through actions and how they felt as a consequence of those actions. Different theoretical models present different approaches with a variety of possible expectations. But do these models recognize the complex changes in contemporary planning practice? Many of those interested in the topic argue they do not. How then, do planners prepare for controversy?

\section{Focus on Education As Force for Change}

Forester (1994) in his discussion on advocacy planning and the challenges of balancing interests for planners writes that in day-to-day work, notions of interest and community are politically shaped--not only by planners' imaginations, but by who speaks and who does not, who attends meetings and who does not, which interests have articulate and effective advocates and which do not. Suggestions of "interest" and "community" are constantly put forward and interpreted. constructed and reconstructed. He goes on to add that conflicting. ambiguous and evolving situations present planners not just with potential confusion, but also with many opportunities. For example in between the naive assumption that interests are always changeable and the presumption that they are fixed is the arena in which planners actually have to work and learn as they go. But this is the arena of democratic politics: of inevitable limited time, poor information, competing views, suspicious and conflicting parties, loud and not always happy voices. Democratic politics and planning processes mean conflict and argument, contention and debate. which are a good deal easier for theorists to write about than for planners to encourage 
and facilitate; especially when the planners are responsible for getting things done and serving may interests at the same time.

\section{Current Planning Research}

Baum (1988) feels that the current research grows out of the concerns which stimulated empirical study of planning. One was planners' growing complaints that their reports were ignored. The second was citizens complaints that, contrarily, plans for urban renewal and its descendants were being implemented and were harming communities. Both concerns led to a focus on the politics of planning: who influenced decisions, and whose interests did they serve. These writers emphasized the inescapable political meanings of seemingly "technical" analysis. In compensating for past oversights by concentrating on the methodology of planning, they tended to suggest that planning is, if not only politics, at least mostly politics. Many researchers have emphasized a new situation as the determinant of planners' actions.

According to Forester (1994), fostering and indeed democratizing public debate requires special abilities from planners: diplomatic skills of listening, acknowledging. negotiating, mediating, probing, inventing, reconciling. facilitating, organizing, and more. Without these skills, planners will seek refuge in expertise and bureaucratic inaccessibility. They will anticipate the prospect of debating plural plans with fear, not relish...... How do the most skillful planning practitioners respond to both the specific interests and visions of "community"? How do they not only respond to "I want; but also illuminate and

encourage We can"? To ask such questions is a matter in part of rethinking planning education--of recognizing that planners learn at least as much from insightful stories as from social scientists' studies of what works under what conditions. Concerned about 
how they might act in the face of contentious public meetings, where the organized threaten to drown out the less organized, where the affluent have lawyers and the poor have other things to do that evening, planners can learn in several ways. From reflecting upon their own experience, and also by watching others, from listening to dramatically vivid and emotionally realistic accounts of how another planner handled a case, or from reading thoughtful commentaries on actual cases. If the bad news is that social science provides know-what rather that know-how, the good news is that judgment and practice can be learned and taught, perhaps coached. This can be happen not only via quasiscientific studies, but through insightful stories, relevant examples, and critically examined experience as well. So planning education must complement model-building in labs with community-seeing in fieldwork, solving technical problems with listening and responding to ambiguous expressions of needs and interests.

\section{Focus on Codes}

Sue Hendler (1994), asserts professional planning codes may play a number of roles. They may express normative ideals for the profession, provide pragmatic guidelines for everyday behavior, communicate to clients and employers the expectations that are warranted in terms of roles and responsibilities of professionals and instruct the public, and students of the professions about the purpose and perspective of the profession. It is this multi-faceted nature of professional codes that make them subject to problems as well as promise. 


\section{A Remedy for Planners}

In responding to a request for action to the planning profession's commitment to equal opportunity espoused in the AICP Code of ethics, Feld (1986 and 1989) challenges planners to pursue the professional commitments in all cities by rejecting artificial constrains on the scope of the profession. She asserts that planners, by drawing upon their professional ethical commitments, can lead a process to provide a socially and economically equitable future for their communities. The broad-based comprehensive approach grounded in participatory planning and built upon special knowledge of communities within the moral imperatives of the profession will allow planners, in concert with government and citizens, to bring about choice and opportunity and, ultimately, the socially just city.

\section{Focus on Personal Characteristics of Planner}

Challenging the posture of these arguments, Baum (1988) asks -- if planners are in fact persons in situations--, then it is reasonable to ask what about their personhood influences their actions in conjunction with situational elements. Most observers give deserved weight to a variety of abilities and skills in both analysis and politics, but planners are much more than toolboxes. The question becomes what else about them affects their practice? In order to understand why planners plan as they do, future researchers must look at the situations planners encounter, their actions in these situations, and the personal characteristics influencing their actions.

Baum (1988) warns that some planning education proceeds without an empirical answer to a fundamental question: Why do planners plan in the ways they do? He suggests that only a systematic examination of what planners do in particular situations will make it 
possible to examine this relationship between planners actions and the context in which they act. Do the situations largely determine the actions? Or do planners act in ways congruent or not with their situation? Studying planners' personal characteristics is important because it will help to answer the question: when situations offer planners discretion (as nearly all do), why do they act in the ways they do?

Krumholz (1982) challenged the importance of something the planning literature usually does not address; the planner as a distinct force in affecting the outcome of decisions. Planning literature conveyed notions that planners are locked into predetermined activities unless they have a base of power, have supportive clients, face few barriers from others, and perform objectives of professional planning. Many writers agree that these and other contextual factors are important to the outcomes of planners activities. However, as illustrative of Krumholz experience, the personal inclinations of the planners. such as willing to take risks, to be assertive, and to confront conflict rather than avoid is also important to the outcome of planners work. A planner's personality can indeed be an important factor in determining what course planning follows and what it can accomplish. For that matter, personality can also work to hinder the opportunities of planners who may be overly cautious and security minded.

\section{Prescriptions For The Future of Planning}

Since situations are defined by planners and the profession as being ambiguous, discretionary and not readily defined, many current writers share some common prescriptions for the direction of future planning research. One is that researchers need to examine the behavior of practicing planners in order to identify the influences on their 
role, and in particular, their role in difficult situations that present ambiguity and discretion.

According to Feld (1989), planners have responded in a variety of ways to the ethical dilemmas arising in public policy decision making. There are a wide range of responses that planners can make to ethical challenges. Questions which relate to critical concerns for planning educators and practitioners include: What are the responsibilities of planners in applying their knowledge of the complex dynamic of communities to situations involving political conflict? What are the roles and responsibilities of the professional planner in a politically troubled situation? Does a planner who "gets along by going along" bear a moral responsibility for the political outcome? What guidelines or yardsticks are being taught to prepare planners for making the ethical and moral choices that are inherent in these situations? What is being taught to provide the will and skills necessary to implement such decision?

\section{IMPLICATIONS}

Since most planners work in public sector, ambiguity and discretion are important concepts that deserve careful consideration. However. according to Forester (1994) planning and planning theory are in no more crisis today than are the humanities and the social sciences generally. When different "paradigms" compete and pose problems differently. that is a sign of health, not intellectual poverty. We should stop looking for a unified field theory, a single common measure of excellence. or for a happy consensus in which architects and economists will love each other. and we should instead explore the real possibilities to improve planning practices so they serve human need. Even with this 
one issue of democratic deliberation, some will approach the issue via political economy, some via computer-based decision support systems, some via psychology and groups processes, and some perhaps through the uses of visual imagination. Our task is not to force a choice among such approaches but to learn what is yet possible, to build on the best available work to see more that we saw yesterday, to be able to share the results with one another, and to be able to listen and respond, to act better as well.

\section{Ethics And Planning Education}

Kaufman (1993) writes that ethical judgments are involved, sometimes explicitly but more often implicitly, in may planning activities including collecting and analyzing data, forecasting. cost-benefit analysis, dealing with the public, administering and managing programs. drafting plans and policies, and implementing plans. Part of the challenge to those teaching ethics in planning schools is to help charge up the ethical batteries of students so that they see more clearly the pervasive ethical dimensions involved in planning work. Planning students need to be appraised of the ethical norms of the profession they are choosing to enter. This means exposing them to the provision of the codes of planning ethics and to the views of reflective educators and practitioners about what is right and wrong for planners to do. At the same time, there needs to be balance to avoid teach ethics in a way that is too strongly normative. That is, only one right or wrong thing to do. Planning students need to have an understanding of the kinds of ethical issues and dilemmas that planners actually face in their work. These issues can range from being pressured to change professional judgment, to being tempted to manipulate information, to reconciling conflicts between loyalty to one's employer and 
loyalty to the public interest. Reporting the results of studies of ethical view of planners, playing portions of taped interviews of planners, and inviting selected planners to speak in class about the ethical dilemmas and how they resolved them are useful ways of bringing a reality to the dimension of the classroom environment.

According to Marcia Feld (1989), responses to question about the responsibilities of planners in applying their knowledge of the complex dynamics of communities and situations involving political conflict are generally centered around the ethical concerns of the planners' moral imperative to validly apply professionally shaped knowledge and values when employed by a community whose majority political consensus is contrary to that of the profession's commitment to the Just Society.

On the issue of the role of the planner, Hendler (1991) asks whether planners should do only what is asked by an employer or develop a professional stance on an issue and stick to it even in the face of adversity? While educating planning students to believe that they will be able to solve problems on their own and in a vacuum is misguided, it seems that it is equally wrong to train planners to do merely what they are told. What is the value of professions other than the recognition of the importance of independent professional judgments? Hendler believes that planning students need to develop the tools of ethical analysis: taking a systematic approach to examining situations in order to arrive at bases for informed ethical judgment; and to facilitate its application in the planner's work life. She adds further, if planning has its own set of ethical concerns and values, these deserve to be identified and discussed. This can occur in the pages of a journal, inside the walls 
of a meeting room in which a new or revised planning code is being discussed, and in the classrooms and hallways of academe. There is opportunity and challenge here for practitioners, students, and educators alike to extend planning education and practice to encompass matters of moral discourse, focus attention on the dynamics between individual and organization, generate dialogue on ethical issues, and forge new principles to which the profession may aspire.

\section{Commonalties and Differences of Theoretical Perspectives}

Common themes that were brought out in the literature review include:

- agreement among writers on the present tension between the technical, political, and social aspects of planning; and the need to address ways of better linking theory and practice

- traditional theoretical role models did not account for the complex society in which planners work today

- ambiguity and discretion in planning practice are indicators of the problematic status of the role of planners and perhaps the legitimacy of the planning profession.

- there is a need to know more about the experience of contemporary planners work lives and their professional problems in the practical setting

- there are a variety of ways to address these planning dilemmas professional codes of ethics and conduct for the planning profession, assumes that professional and societal consensus are possible 


\section{Differences}

Baum (1988) offers the most striking criticism of both traditional and current approaches. He offers an alternative to planning research approaches, and challenges those interested in the planning profession to think in a different framework. He suggests that research emphasizes situational influences on practice while ignoring the personal characteristics of planners. He adds that those who write about planning tend to write about planning situations as the determinant of how planners should act. He proposes that research explore individual characteristics of planners' personalities as the determinant for action.

\section{THIS PROJECT}

Research on effective ways of linking theory and practice has been going on for many years. As stated earlier, the focus has shifted from theoretical models discussing the role of the planner as technical advisor, to that of a more active participant in the planning process. With the evolution of demands on the role of the planner from both the public and the agencies whom planners work for, recent research examines what planners should do in certain given circumstances. This project presents a participant-observer, qualitative case study (Yin, 1989) of actual events during a nine week time of perceived controversy in a rural town setting. The purpose is to better understand the whole role of the planner, and identify the influences which played a part in determining the actions of the planner in the case example. 
According to Schon (1982), there are many dangers associated with the detailed description of a single case, especially a case drawn from a single episode in a professional life. Doubtless, not all town planners are like the one in this study; further, the rest of the writer/planner's practice may differ in significant ways from the episodes discussed. A fuller research program would analyze many episodes drawn from the life of a single planner, and would juxtapose the experiences of many different sorts of planners. Nevertheless, the case example attempts to highlight several common themes in contemporary dilemmas identified by practicing planners. In the case study, the qualitative research design draws substantially on theoretical perspectives on characterizing the influences of planners roles in situations with ambiguity and discretion. This type of case study is descriptive; its general analytic strategy describe a broad topic of professional planner's roles. The unit of analysis is the role of the writer/planner and her actions which resulted in professional and ethical concerns as experienced in context of the case example. The units of observation are the events and the subsequent actions that unfolded. The framework of analyses of this project is based upon the current literature which explores the dynamics of planning behavior relative to concepts of:

1. the content of planning theories and assumptions; what expectations and models--what influences-- and informs the practicing planners role 2. the context of planning practice, that is, the situations, settings, conditions, and circumstances in which professional planners work 
In addition, the developmental framework utilizes models from ethical perspective articulated by Howe and Kaufman and others, as well as assesses the influence of personal characteristics in accord with Buam's thesis.

\section{Motivation of Writer/Planner}

Professional ethics in planning are centrally concerned with the relationships between expert career staff and the elected decision makers and citizens they are supposed to serve (Howe, 1994). When the writer/planner of this case study reflected on the various situations experienced during the study period, these same relationships were examined. Recent research has involved descriptive analyses of the perspective of practicing planners regarding ethical issues that arise in their work lives. Howe and Kaufman state that the intention is to describe what planners think is ethical, not to judge whether or not planners are ethical by some predetermined standard. This paper is not an evaluation of the actions of the planner, that is whether they were good or bad, right or wrong, rather the purpose is to attempt to add to the discussion and exchange of ideas of theoretical influences which impacted upon the behavior of the planner in the case example. 


\section{CHAPTER TWO: THEORETICAL FRAMEWORK}

Planning knowledge is analyzed as a system of knowing-in-practice which includes the framing of role and situation, and in the interpersonal theories of action which the practitioner brings to his practice (Schon, 1982). 


\section{Introduction}

This is a participant observer study and as such, the initial assessment of activities involves a chronology of events whose actions represent relationships between the role of the planner and the behavior of various participants. The process of this model assess this project by facilitating the articulation of professional and ethical judgments in this planning process as experienced in the case example.

Most of the models described in Chapter One employ a qualitative study design which analyze a variety of topics. In this case example, descriptive steps are used whereby potential factors explain why the writer/planner behaved as she did during the time of study. Although the narrative in Chapter Three is extremely detailed in recounting the events, the details build a more unified understanding of the question under study: what influences impacted the actions of the planner as shown in the case example and why.

\section{Method of Analysis}

The analysis in this qualitative case study might be likened to assembling a jigsaw puzzle whose picture is not quite clear until it is all laid out. Once the various parts are assembled and discussed, the relationships will be established, roles identified, and actions interpreted (Schein, 1987). This qualitative case study and method of analysis is designed to identify areas of greatest concern during the study period. The method assigns values to the relationships between the planner and the elected town officials and 
the local residents. The analysis focuses on three actions identified as key professional planning activities which resulted in professional and ethical concerns. These actions, taken by writer/planner in the case example are specifically described in the narrative of Chapter Three, and are summarized below in Table 1.

\section{Table 1. Professional Activities and Ethical Concerns of Case Example}

\begin{tabular}{|c|c|}
\hline Professional Planning Activities & Ethical Concerns Relative to Action \\
\hline $\begin{array}{l}\text { 1. research, prepare, and distribute } \\
\text { technical data on casino gambling } \\
\text { development project (the substantive issue) }\end{array}$ & $\begin{array}{l}\text { 1. what is the obligation to which client-- } \\
\text { who is the decision maker? }\end{array}$ \\
\hline $\begin{array}{l}\text { 2. identify resources and propose various } \\
\text { strategies for information dissemination } \\
\text { through public forum/meetings }\end{array}$ & $\begin{array}{l}\text { 2. what is the obligation to commitment to } \\
\text { initiate a participatory decision making } \\
\text { process which will be responsive to the } \\
\text { public? }\end{array}$ \\
\hline $\begin{array}{l}\text { 3. place casino gambling development } \\
\text { proposal in Planning Board Meeting } \\
\text { Agenda }\end{array}$ & $\begin{array}{l}\text { 3. what is the political pressure from } \\
\text { elected and appointed officials on the } \\
\text { professional judgment of the planner? }\end{array}$ \\
\hline
\end{tabular}




\section{Assessing Relationships}

The analysis will include theories of various factors that operated within the planning process and ended with consequences. Selected models for analysis will assess relationships between writer/planner, the elected officials, and local residents with a focus on the motivation for a set of decisions made in response to professional and ethical concerns. As such, additional concepts will be discussed throughout the project that refer to the "observable" elements of the planning process, that is, writer/planner's visible actions: speaking, attending meetings, conducting interviews; writing correspondence and performing procedural activities. "Unobservable" elements of the planning process include writer/planner's thoughts, feelings, and value commitments that shaped actions in the case example. Tactics and outcomes examine these factors which facilitated or constrained attainment of objectives within the planning process. Chapter Four, will discuss the findings and conclusions of the project analysis.

\section{Explanation Of Development Framework}

The developmental framework for assessment will utilize a variety of empirical models found in studies conducted by selected authors. The models are specifically designed to analyze the behavior of practicing planners in situations which present professional and ethical dilemmas. Selected models are developed in three steps: to describe the contextual characteristics of the controversial situation; to assess the ethical behavior of 
writer/planner; and to explore the personal characteristics that influenced writer/planner's behavior in the case example.

\section{STEP ONE: Contextual Characteristics}

According to Elizabeth Howe (1994), three steps are necessary for effective, ethical behavior. Planners must be able to identify situations as posing ethical issues; that is, how does a planner perceive a situation as one of conflict and/or controversy. Once an ethical issue has been identified, the planner must be able to articulate the situation as such and decide what should be done about it. In the last step, the planner must have both

the will, and the freedom or leverage to act on her or his own decision. The model used by Howe and Kaufman (1981), in their work "The Ethics of Contemporary American Planners", will be utilized to describe the manner in which writer/planner responded to issues in the case example. More specifically, the developmental framework will use the model to frame a description of each component: the scenarios which describe the type of actions taken to intervene in the situation; the tactics which explain the motivation for action; and the intended issues benefiting which define the ethical concerns raised by writer/planner. Actions will be assessed, in terms of their relationship to outcomes, and discussed in the findings section of this report. 


\section{STEP TWO: Assessing Ethical Behavior}

Writer/planner in the case example identified ethical issues of concern, therefore models which examine the ethical perspective of the planner's experience are utilized. Elizabeth Howe (1994) in her empirical study of the ethics of planners in "Acting On Ethics In City Planning", asserts it is quite possible to have an explicit, reasoned standard against which ethical behavior can be judged. The starting place for the normative framework for assessing the actions of the planner is the AICP's Code of Ethics and Professional Conduct (American Institute of Certified Planners 1981; revised version 1992) (See Appendix). The nature of such a code is to lay out principles that apply universally, at least in the professional context, and that would encourage consistency of application.

\section{Nature of Ethical Issues}

Issues of social justice and loyalty to agency do not come up every day in planning practice, but choices about how active a role the issues should play are fairly common in contemporary planning practice. All are issues of practicing professional ethics and are not abstract. These are issues that are dealt with in the professional organization's code, and are conflicts that arise in everyday practice because the planners themselves have their own professional value commitments about loyalty and social justice. Planner's values are not all the same nor are their images of the kind of role they should play. So the answers to ethical issues are likely to be different from one planner to the next. 


\section{Ethical Framework For Planning}

According to Howe (1994), a code of ethics set the boundaries of acceptable behavior for planners. In theory, a set of commonly held behavioral norms make up the body of professional ethics. Some, but not all of these norms have been codified in the Code of Ethics and Professional Conduct of the American Institute of Certified Planners (AICP; formerly the American Institute of Planners) (1981). Whether codified or not, these norms ideally represent guidelines for planners in conducting themselves as professionals. The code is a lengthy statement on the planner's responsibilities to the public, clients and employers, the profession and colleagues as well as one's self. The preamble of the code states that:

"This Code is a guide to the ethical conduct required of members of the American Institute of Certified Planners. The Code also aims at informing the public of the principles to which professional planners are committed. Systematic discussion of the application of these principles, among planners and with the public, is itself essential behavior to bring the Code into daily use.

The Code's standards of behavior provide a basis for adjudicating any charge that a member has acted unethically. However, the Code also provides more than the minimum threshold of enforceable acceptability. It sets standards that require conscious striving to attain" (Howe, 1994: 212).

\section{The Planner's Responsibility}

The AICP code is structured around the idea of obligations to various groups served by planners. The primary obligation is seen as the planner's responsibility to the public and to serving the public interest, which is defined in both procedural and substantive terms. 
In addition, secondary obligations are owed to clients and employers, to colleagues, to the profession and finally, to the planner himself or herself.

The code also forms a hierarchy in which some principles are more binding than others. Thus, laws and duties are the most binding principles; accountability and service to the public interest are second; and principles concerning responsibilities to the profession constitute a third level of obligations. The rationale for this hierarchy is both theoretical and empirical. The correspondence between the hierarchy and what planners were already doing would not, by itself, justify its use, but if independent arguments can provide justification, the correspondence would seem to be a practical advantage.

\section{Working In Public Bureaucracies}

This research project is a study of a planner acting in a public sector position, as is the study by Howe (1994). She claims that city planning is different from the traditional dominant consulting professions, such as law and medicine, which have been the focus of most discussions of professional ethics. The primary difference is that the predominant work/employment is as career staff in public bureaucracies. It is these public planners who are the subject of study. As career staff, planners work in public bureaucracies and have input into the outcomes of planning decisions but certainly do not control these outcomes. Planners are officially charged with serving the interests of a whole community, rather than individual clients. Planner's own values concerning the best ways to serve the public interests of the community are only one element in a complex 
process of determining public policy. Their expertise and their professional charge relate to developing plans and recommending implementation strategies. The process is likely to involve considerable input by citizen groups and by those who have a direct financial stake in the plans and their implementation. The final decisions are made ultimately by elected and appointed officials.

\section{Hierarchy Of Principles}

Professional ethics in planning are centrally concerned with the relationship between expert but not elected career staff and the decision makers and citizens they serve.

The framework for this study is an articulated hierarchy of principles as presented in the AICP Code. According to Howe (1994), at the top of the hierarchy is the planner's adherence to the civil law. Next is adherence to ethical duties of justice, and two coequal principles of accountability and service to the public interest. Planners must respect laws and duties of justice. Such duties of justice are basic ethical norms which allow for predictability and trust among individuals. They include honesty, truthfulness, fairness. and promise-keeping. The principles of respect for laws and for duties of justice are followed by two counterbalancing principles. One is the requirement that non-elected bureaucratic officials be responsible to the public. sometimes directly, but more typically by being accountable to elected officials. The other is that they serve the public interest. 


\section{Defining The Public Interest}

Accountability to the public through elected decision makers is a long-standing tenet of democratic administrative theory. Even though our understanding of the relationship between politics and administration has changed over the years and our acceptance of the absolute legitimacy of elected officials has been somewhat tempered, this is still a central tenet. Public servants, such as planners, work in public bureaucracies that institutionalize this relationship of responsibility. While they have never been given the kind of autonomy that has been granted to consulting professionals such as doctors or lawyers, autonomous action is still grounded in processes that allow for oversight and accountability (Howe, 1994). The problem with the ethical obligation to be responsible is that it can be interpreted as a requirement for unconditional personal loyalty to elected officials, regardless of the legitimacy of their demands.

\section{Planners Knowledge}

The counterbalance of planners to claims of loyalty is their professional judgment. They draw on bodies of technical knowledge and methods to assess means for accomplishing ends set by elected officials. In addition, planners have their own values about what kinds of policy will best serve the public interest. However, practicing planners use the idea of the public interest as a common guide in their work. They generally mean by it one of two things that are not mutually exclusive: 1.) substantive contents such as concern with social justice or the broad, long range good of the community: and 2.) a 
process of ideas of the public interest and those held by elected officials and members of the public.

\section{STEP THREE: Examination Of Personal Characteristics}

Even though ethics are not legally mandated codes of conduct, they are enforced in part by social pressures among people who share the same organizational, professional, or cultural systems. Their effectiveness depends considerably on being embodied in an internalized professional sense of right and wrong, and of good and bad. The question of what influences a practicing planner to not only embrace the norms of professional practice, but act accordingly, some scholars believe is of greatest concern for the planning field.

The model used by Howell Baum (1988), in his study "Why Do Planners Do What They Do? The Little We Know and The Lot We Don't", is utilized to articulate specific personal factors that influenced behavior and shaped action in the case example. More specifically, this model is utilized to explain the thoughts. feelings and value commitments which shaped writer/planner's role in the case example.

Baum (1988) believes what is studied in research is not how planners should act in certain situations and under certain circumstances, but rather, what should be looked at more closely in the future is what planners actually do in these situations. The future of planning should study planners as persons-in-situations because, when situations offer 
discretion, as they all do, it may be beneficial to know why planners plan as they do. He recommends a research strategy of three equally important elements to study:

1. analyze the situations in which planners practice; situations are defined in terms of role expectations for planners;

2. actions or practice of planners; what do they do; the relationship between planners action and situations in which they act; action is defined in terms of:

(a) observable activities are defined in terms of what planners do --speaking, attending meetings, writing documents, and analyzing certain technical data; and

(b) non-observable aspects are defined in terms of exploring what underlies activity; the factors that influence the thought process and are not readily accessible to observation -what was included in the process and what was excluded, and why; how do people anticipate. think about, and plan conversations

3. personal characteristics of planners include: biography. cognitive style, and personality type --can planners act logically and deliberately without interference from personal characteristics, unconscious or irrational thoughts and wishes?

The combination of models and developmental framework will be used to organize the findings and conclusions of this report. 


\section{CHAPTER THREE: CASE STUDY}

"I think it's important for Rhode Island to participate in this gaming industry...I think any governor of Rhode Island would be irresponsible if he did not get involved." Governor

Bruce G. Sundlun (quoted by Thomas Frank, in The Providence Joumal, Aug. 29, 1994) 
This chapter is divided into three sections. The first is context with the attendant conditions, and a summary of the nature of the substantive issue as experienced in the case example. Section two presents perspectives of gambling as perceived by participants in the community of West Greenwich and other key stakeholders. Section three provides the chronology of events during the nine week study period. Section three is narrative in style and was assembled from various communication records which were maintained by the writer/planner during the study period.

\section{CONTEXT}

In order to better understand the community that serves as contextual backdrop for the project, following is a brief profile of the town of West Greenwich.

\section{Land Use Patterns}

Rhode Island, like most of the United States, has experienced a shift in population and settlement patterns from the central city to less developed suburban and rural communities. This pattern within the state, is expected to continue and be intensified by any development which follows the major highway, Interstate Route 95, which bisects the state from north to south. One of the towns along this primary route is West Greenwich. A large rectangle, West Greenwich has a total land area of approximately 35,000 acres, or 50.6 square miles. It is bounded by the state of Connecticut on the west, the town of Coventry on the north, East Greenwich on the east, and Exeter on the south. State Route $102 /$ Victory Highway runs north-south through the center portion of the town and crosses Interstate 95 and Route 3 near the Exeter town line. There are no major east-west 
arterials across the town, virtually no traffic signals, and many unpaved town roads (See Figure 1. West Greenwich Road Map).

Over one-third of the town's total land area is state owned, and used for parks and recreation. Potential future development may include portions of the Big River Reservoir, land the state obtained in 1962. Currently, this area is used for residential, low-end market-rate housing. The W. Alton Jones Campus of the University of Rhode Island, which has 2300 acres, is located in the town and is used as a research facility, camp and conference center (See Figure 2. West Greenwich Land Use Map).

\section{Increased Growth Pressure}

In spite of recent development, the town remains the second most sparsely populated area in the state. However, the town has experienced a consistently high growth rate in the past several years. According to the U.S. Bureau of Census for 1990, population figures for the town were 3,492 which represented a 27.5 percent increase from the 1980 population figures, and West Greenwich ranked number 37 in population among Rhode Island's 39 cities and towns. During this same reporting period, the population density of the town was 68 persons per square mile of land area. Total housing grew from 490 to 1370 between 1960 and 1990 which represents a 36 percent increase (U.S. Census, 1990). However, the census figures do not tell the entire story of growth that affected the town during Rhode Island's building boom of the 1980s. According to former town planner, Ann Skiver, the challenge of the 1990s will be to preserve the rural character and "country living" quality of life that originally attracted so many of the newcomers. 
Ambrose Knight Road ***** APACHE COURT

Arthur Richmond Road

BAILEY DRIVE

BAIEY POND ROAD

BARNEIT LANE

BATES TRAIL

BIG RIVER ROAD **

Blueberry Heights

Brant Trail

BREAKHEART HILL ROAD

BROWNS CORNER ROAD

BURNT SAWMILL ROAD **
CAMBIO COURT

CARRS POND ROAD

CEDAR POND WAY

CHEROKEE TRAIL

CHEYENNE TRAIL

CLUB HOUSE ROAD

COMANCHE TRAIL

CONGDON MIL ROAD **

DAYNA DRIVE

DEER RUN DRIVE

DIVISION STREET *

DONALO POTTER DRIVE

ERRANT WAY
ESCOHEAG HILL ROAD (PARTIAL *) HOPKINS HILL ROAD ** FALLS RIVER ROAD

Finlandio Boulevard

FISH HILL ROAD

FOX RUN

FRY POND ROAD

Gardner Matteson Lane

Greenwich West

HAMMITT VEW DRIVE

HARRY ANDREWS ROAD

HAZARD ROAD

HEATHER HOLLOW ROAD

HENRY BROWN ROAD
HOXIE ROAD **

HUDSON POND ROAD

JOHN POTTER ROAD

JULIE COURT

KIMBERLY DRIVE

KITTS CORNER ROAD *

LAKE DRIVE *

LEYDEN COURT

UBERTY HILI ROAD

UNDEN LANE

Long View Drive

Maccue Point Road

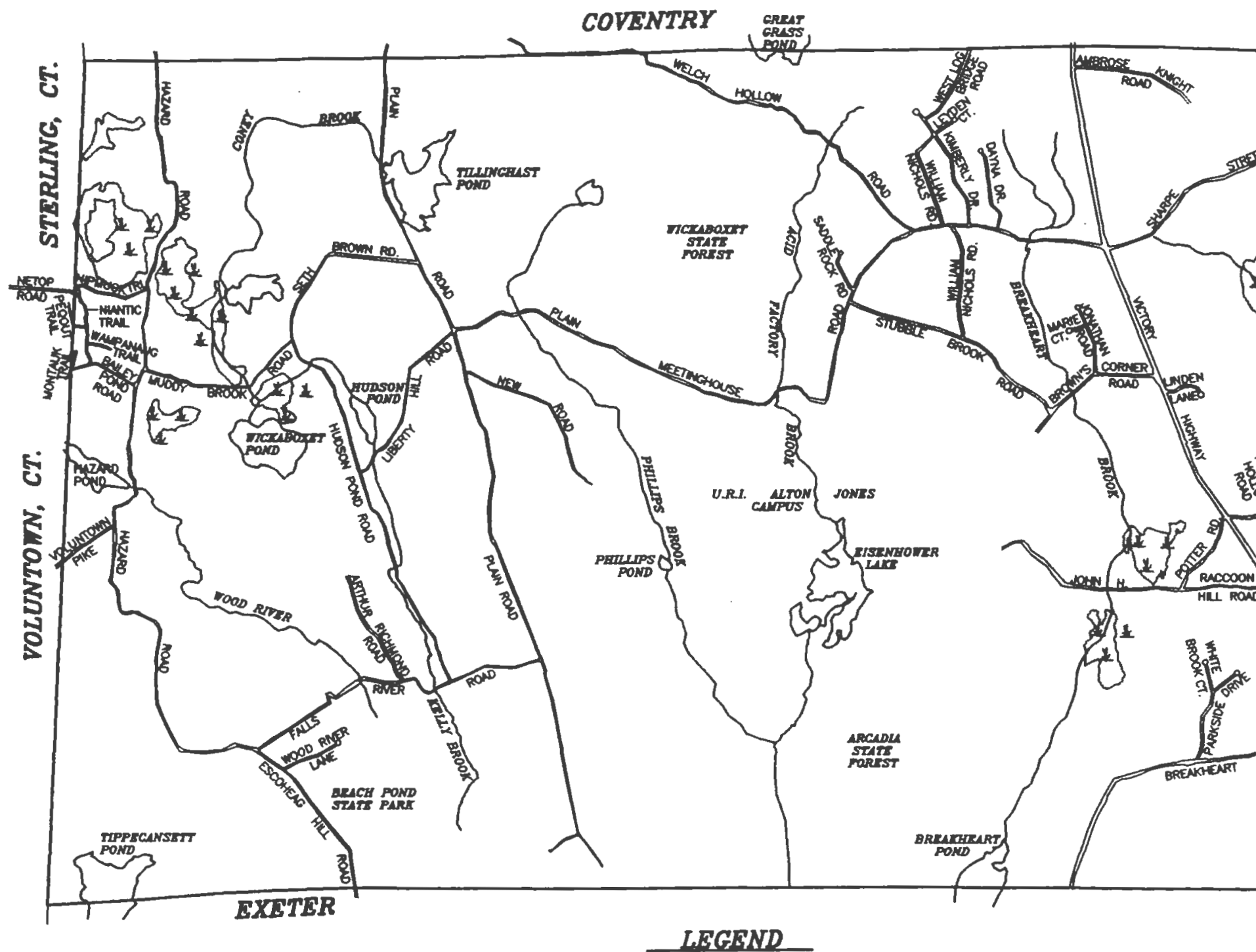

(1) COMANCHE TRAL

(4) CLUB HOUSE ROAD

(7) Maccue Point Road

(10) Rognell Road

(2) SEMINOLE TRAL

(5) CAMBIO COURT

(8) Pine Oak Trail

(11) APACHE COURT

(3) CHEYENNE TRAL

(6) POND VIEW COURT

(9) Long View Drive

(12)

Greenwich West

PRIVATE ROADS - Lower COSe Lotters

TOWN ROADS - ALI CAPTTAL LETTERS

STATE ROADS - .

TOWN OR STATE ROADS =

MINIMUM MNINTENUNCE ROUDS = ..*

PRNATE R.O.W./PARTULY MPRONED =

Note: The information depicted on this map is suitable for planning purposes only. It may not be adequate for legal boundary definition or regulatory interpretation. 
:OURT

XK ROAD

TRAL

Trail

BROOK ROAD

rail

NDON TURNPIKE **

$A D * * *$

Trail

: Trail

ECK HILL ROAD *

¿COON HILL ROAD

$<$ WAY
PARKSIDE DRNE

Pequot Trail

Pine Ook Trail

PINE TREE LANE

PLAIN MEETING HOUSE ROAD

PLANN ROAD

POND VIEW COURT

PUMPKIN HOUSE ROAD ***

RACCOON HILL ROAD

Ragnell Rood

REGINA DRIVE

ROBIN HOLLOW ROAD

ROLAND DRIVE
SADDLE ROCK ROAD

SEMINOLE TRAIL

SETH BROWN ROAD

SHARPE STREET

SQUIRRELS RUN

Stark Drive

STUBBLE BROOK ROAD

SUZANNE COURT

SWEET SAWMILL ROAD **

TANGLEWOOD DRIVE

TECHNOLOGY WAY

TERRACE DRIVE

TOWN HALL ROAD **
VALE COURT

Volerie Drive

VICTORY HIGHWAY *

VOLUNTOWN PIKE ***

Womponaug Trail

WEAVER HILL ROAD

WELCH HOLLOW ROAD ***

WEST LOG BRIDGE ROAD (PARTIAL *** WHISPERING PINES TERRACE

WHITE BROOK COURT

WIUIAM NICHOLS ROAD ****

WILLS SWAMP ROAD

WOOD RIVER LANE

YARD POND ROAD **

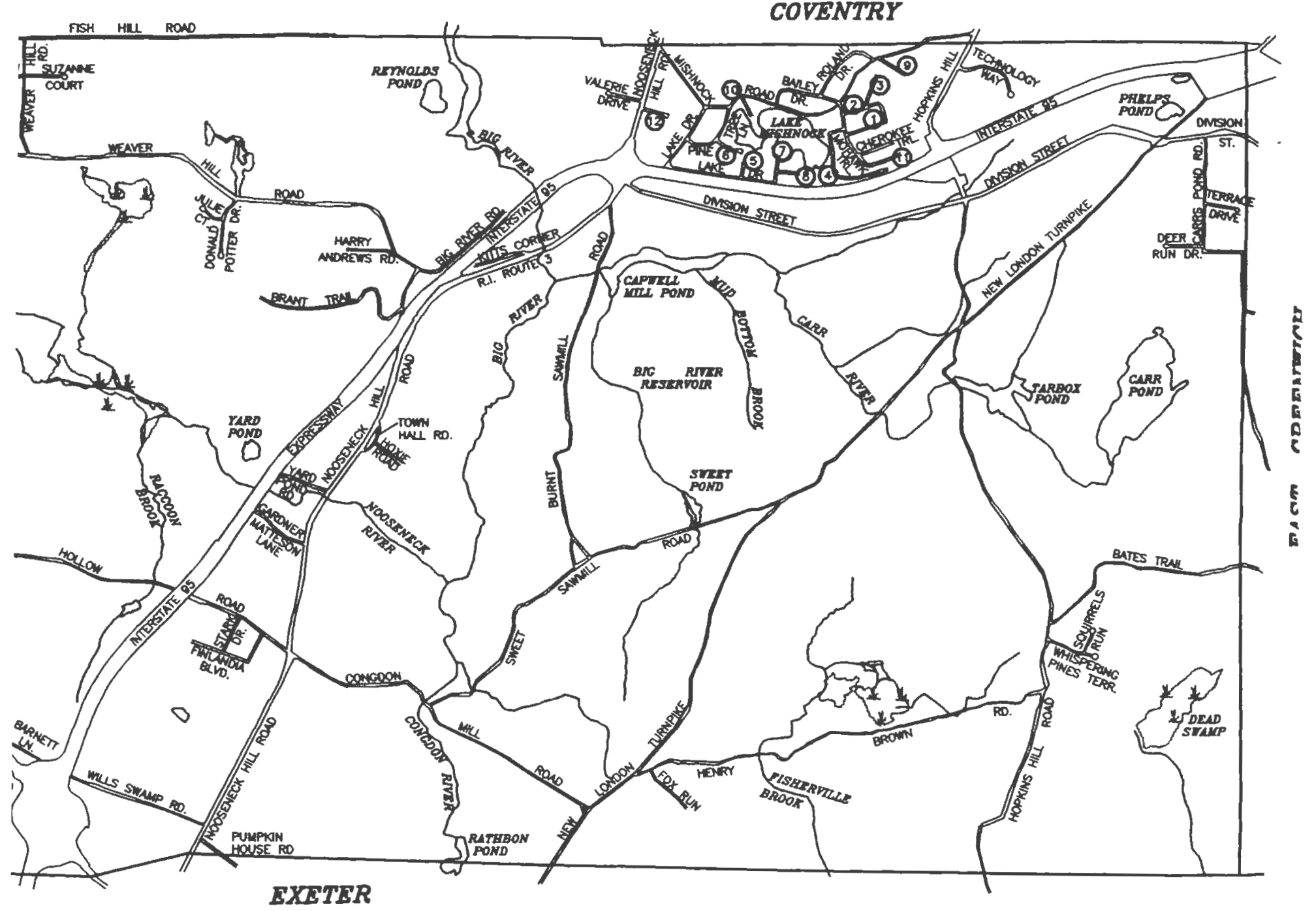

LARSH

$K E$

TOWN OF WEST GREENWICH KENT COUNTY, RHODE ISLAND

SEPTEMBER 15, 1995

ROOK

4200

0

4200

8400

12600 Feet

t Greenwich Road Map 


\section{Infrastructure and Community Services}

Low density has provided for many of the rural amenities, but it has also hindered the development of some other conveniences. For example, West Greenwich residents do not have within the town boundaries, a grocery market; retail outlet or financial services; there is not even a post office. Currently residents utilize shopping facilities and services of nearby communities such as Coventry, Warwick and North Kingstown. Town leaders identified "priority" capital improvements which include improved or expanded public facilities; schools and public works projects; protective services (such as fire and health); and other municipal services. The town's fire and rescue services are on a volunteer basis: and the town employs a limited municipal staff. The municipal offices, as well as the police station. are located in the Town Hall on Victory Highway. Although many local government employees work less than full-time, municipal office space is crowded with workers often sharing desk space. The town's free library is located adjacent to the Town Hall.

\section{Community Fiscal Structure}

There is limited acreage zoned for commercial business, however, small retail outlets have slowly developed along commercially zoned portions on Victory Highway. There are approximately 235 acres of vacant industrial land, with one major industrial park where GTECH and BW Manufacturing, have professional service and manufacturing operations (See Figure 3. West Greenwich Zoning Map ). 



\section{DRAFT}

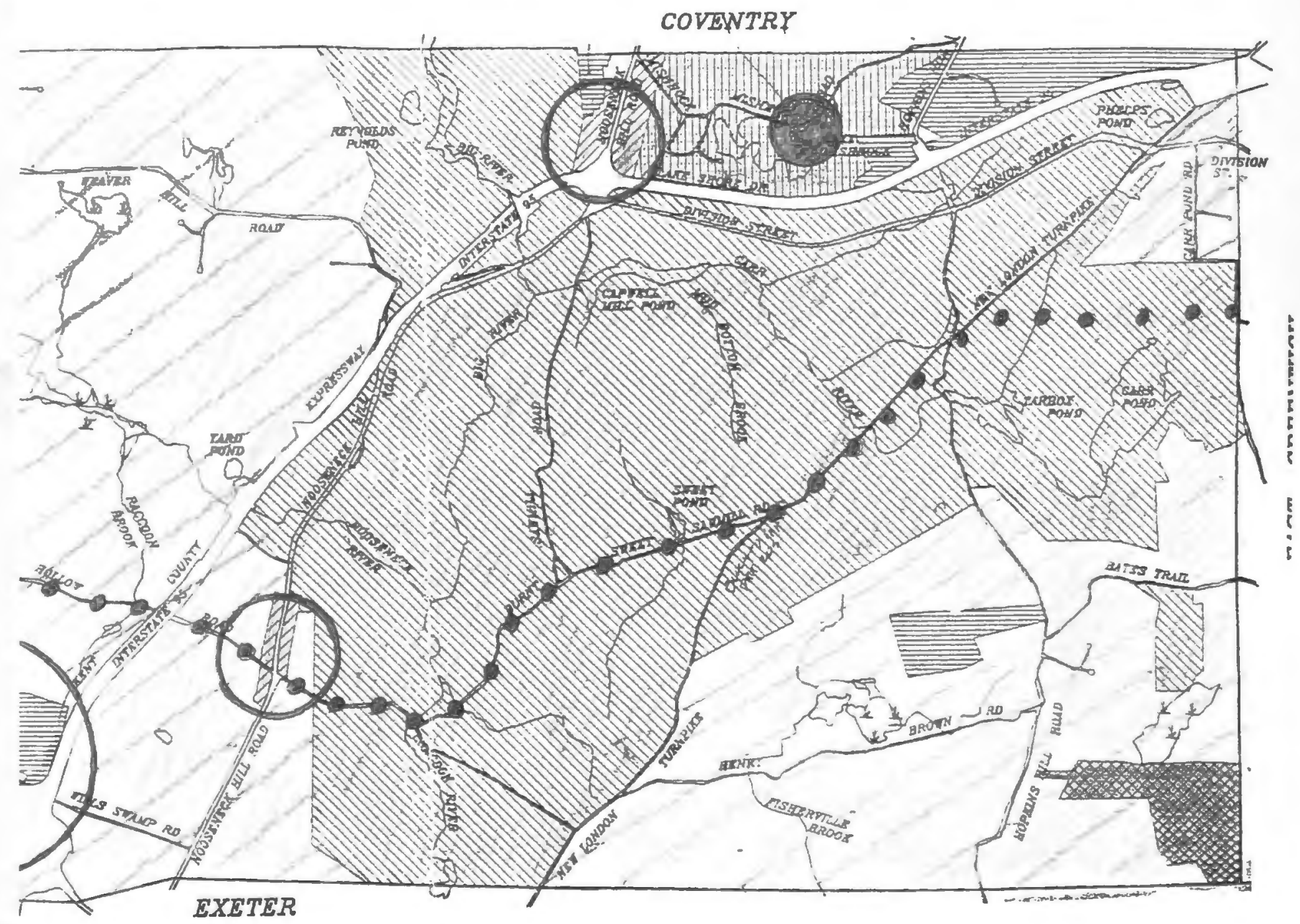

\footnotetext{
Special Area Management p
Mini-plan areas
Industrial "A"
Open Space/ Public Lands/
Recreational use

Industrial "B"

Public Buildings and
Muncipal Facilities
}

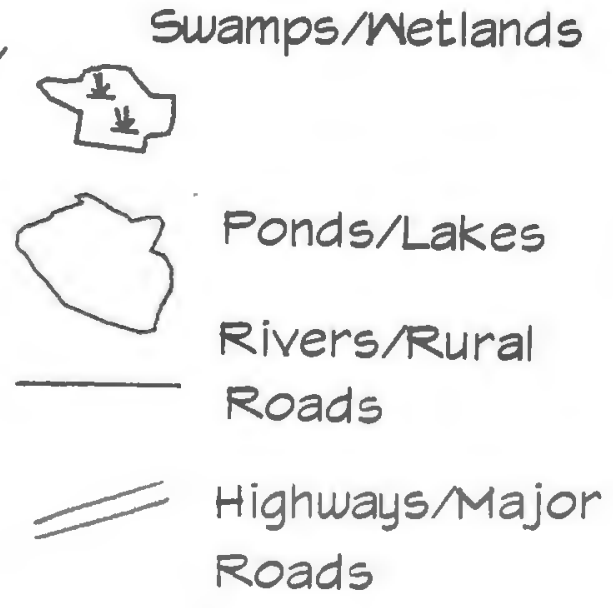

Figure 2:

\section{Swamps/Wetlands}



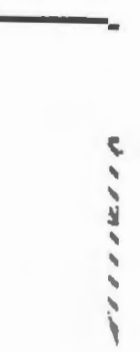

1

4

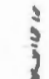

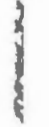

$\vdots$

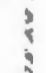

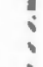

$\vdots$

:

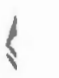

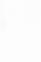

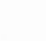


Most of the town's residential land is zoned rural residential/single family, with minimum two acre lot size to accommodate for individual septic systems and private well water.

There are no public sewers in the town, except for the industrial park, which is served by West Warwick Water Authority.

\section{Key Issues And Concerns}

The town has struggled to put into place measures which will control and guide its growth and expansion. One of the key issues that recently gained attention from the town's elected and appointed officials, was the preparation of a comprehensive community plan. Under the Rhode Island Comprehensive Planning and Land Use Regulation act of 1988 (RIGL 45-22.1), each city and town were mandated to develop a comprehensive plan consistent with state agency guidelines. The updated West Greenwich Community Comprehensive Plan would be the first to be authored by the town leaders and residents instead of state planners. According to the former town planner: "the new plan will wrestle with issues responding to the growing pains of the last 20 years, as well as draw a map to negotiate a path through an uncertain future. No matter how small or large, a town that grows 27 percent in ten years is going to experience growing pains." (Skiver, 1991. Public Opinion Survey, Town of West Greenwich).

\section{Community Aesthetics}

The balance of rural amenities and adequate service provision is of central concern to many residents. Newcomers and well-established residents alike, strive to agree on what kinds of services they want, how to pay for those services, and how to channel future 
growth. Policy recommendations of the (draft) community comprehensive plan reflect resident's desire to preserve and protect the rural character, natural resources, and historic features of the town. Local policy makers face the challenge to formulate measures which address constraints and opportunities associated with growth and expansion in their rural community. Over the past several years, the former Town Planner and the Planning Board have worked to ensure the town is able to provide sufficient services and public facilities to meet changing needs, yet remain in sound financial condition. As of December, 1995, the town did vote to finalize the Zoning Ordinance (RIGL 45-24-27 et seq), and the draft Comprehensive Community Plan.

\section{Community Government}

The form of government is a five-member Town Council, headed by a council president. During the time of study, the Town Council consisted of four males and one female, all of whom are life-long residents of either West Greenwich or Rhode Island; each one has served at least ten consecutive years on the council; and each of their political affiliation's is registered Republican (see Figure 4. Organization Chart, in Appendix). Town Council elections are held in November of even numbered years. Council meetings are held the second Wednesday of each month in the Town Hall, and are open to the public. 


\section{ATTENDANT CONDITIONS}

Writer/planner's employment with the town of West Greenwich as interim Town Planner began late March, 1994, and concluded late December, 1994. The focus of this paper is the role of the professional planner within the planning process faced with a controversial issue. The events described in this project are restricted to the nine week study period, beginning with the introduction of the controversial issue (the gambling casino compact) on August 29, 1994. This section concludes with the day prior to the November 8, 1994, election.

\section{Methodology}

In order to present a more valid and accurate chain of events (Yin. 1989), the developmental sequence was assembled from a variety of sources. Those sources include writer/planner`s personal correspondence records, daily planning calendars, meeting notes. and a journal of planning office telephone conversations which were utilized from the inception. to the completion of employment with the town. The narration of events is not exhaustive in detail, but provides insight into the content of the decision making process as experienced in the case example.

\section{Administrative Duties}

The primary concern of the planning office was to guide the physical development of the town. Professional planning activities focused on zoning and subdivision controls for land development. On a day-to-day basis, writer/planner's responsibilities included the overall coordination of the planning department with other municipal offices, Councils, and Boards; inventory maintenance and classification of both active and proposed 
development projects; and the ongoing preparation of the 1990's West Greenwich Comprehensive Community Plan. In order to maintain land use development inventories, writer/planner's primary activities focused on the following:

- prepare and maintain up-to-date inventory of all land development projects in the town; the location, type, and development phase of each

- work with individuals and developers to ensure that land use projects were in compliance with town's planning regulations and policies

- coordinate meetings and schedule site visits with other departments (engineering, zoning, assessors), for process review

- assist in the preparation of monthly Planning Board General Meeting agenda(s)

\section{Introduction of the Substantive Issue (Gambling Casino Proposal)}

Once the gambling casino proposal was introduced, the focus of writer/planner ${ }^{\circ}$ daily activities broadened to include: 1) to monitor the progress of the negotiation activities between members of the town council and the developers, and; 2) to identify and recommend options to decision makers on how to address concerns expressed by local residents. The situation was continually assessed by writer/planner and decisions about data collection --whom to interview, what to observe, what documents to examine--, were based upon the previous day's activities. Information was forwarded to key decision makers and ideas for strategy changes were discussed with various participants in the planning process. 


\section{NATURE OF SUBSTANTIVE ISSUE}

\section{Data Gathering Process}

Writer/planner attempted to research both the local context and the broader social implications of this controversial public policy issue. Writer/planner's approach to planning related activities focused on research which included analyses of archival records to identify existing conditions of the community; and to provide an estimate of the most probable effects of citing the gambling casino development in the community of West Greenwich. In addition, writer/planner utilized technical data collected from courses in Planning Law and Community Based Housing and conducted research at various Rhode Island law libraries, which resulted in a greater appreciation of the various constitutional implications of the IGRA legislation, as well as the Narragansett Indian Tribe's social and legal positions.

\section{Identifying Community Sentiments}

The writer/planner's objective for the above analyses was to expand the physiological focus to include socio-economic considerations of the proposed land development (gambling casino). To meet this objective, research was directed to the Comprehensive Plan 1991, Public Opinion Survey. The findings identified important aspects of community life as expressed by the residents in West Greenwich. More specifically, residents established their preferences for growth controls, expansion of community facilities and the need for expanded public services. Some of the most important characteristics included: 
- most residents value the rural character of the town's setting with the undeveloped natural environment, the sprawling farm pastures, and dense forests throughout the town

- they appreciate the high quality of life in terms of aesthetics--with little noise and congestion;

- many expressed a strong sense of safety and well being due to a low incidence crime and violence within the community

- private automobile is the most prevalent mode of transportation with limited public transportation serving the town

- property valuation was a concern; with increased migration, higher property taxes were causing some personal hardships

- existing regulation provided for adequate buffers between land uses, such as the industrial park and residential development many expressed concerns about the provision of adequate town services; for example. roads needed repair, schools were overcrowded, and municipal offices were understaffed with fire and rescue service provided on a volunteer basis 


\section{Technical Reporting Process}

A summary of the existing conditions; and the potential opportunities and constraints, represented by the proposed gambling casino project, is represented in the table below.

\section{Table 2. Analysis of West Greenwich Casino Gambling Proposal}

\begin{tabular}{|c|c|c|}
\hline Existing Conditions & Opportunity/Compatible & Constraints/Conflict \\
\hline $\begin{array}{l}\text { 1. Land Use Patterns } \\
\text { primarily single family, } \\
\text { residential pattern of development }\end{array}$ & $\begin{array}{l}\text { expands commercially zoned } \\
\text { areas of town }\end{array}$ & $\begin{array}{l}\text { high density land use; out of scale } \\
\text { with rural setting and open space } \\
\text { and undeveloped forested lands; } \\
\text { land use regulations permanently } \\
\text { waived under IGRA legislation }\end{array}$ \\
\hline $\begin{array}{l}\text { 2. Transportation } \\
\text { primarily rural arterial linkages; } \\
\text { no traffic signals within town } \\
\text { boundaries: limited public } \\
\text { transportation }\end{array}$ & $\begin{array}{l}\text { site has high visibility and easy } \\
\text { access to interstate highway } \\
\text { interchange and with local arterial } \\
\text { road network }\end{array}$ & $\begin{array}{l}\text { facility classified as high trip } \\
\text { generator and travel patterns may } \\
\text { impact adjacent residential areas }\end{array}$ \\
\hline $\begin{array}{l}\text { 3. Demographics } \\
\text { population characteristics: } \\
\text { population density is lowest in } \\
\text { state; residents are } 98 \% \text { white: } \\
66 \% \text { married couple families; } \\
\text { median age is approximate } 34\end{array}$ & attract more diverse population & $\begin{array}{l}\text { effects of migration: } \\
\text { projected population growth } \\
\text { impacts pressure for controlled } \\
\text { development }\end{array}$ \\
\hline $\begin{array}{l}\text { 4. Housing } \\
\text { Stock is primarily new } \\
\text { construction; owner occupied; } \\
\text { market price is } 69 \% \text { between } \\
\$ 100.000 \text { to } \$ 200,000\end{array}$ & $\begin{array}{l}\text { greater diversity in housing type } \\
\text { and affordability }\end{array}$ & $\begin{array}{l}\text { property valuation fluctuates } \\
\text { relative to site location }\end{array}$ \\
\hline $\begin{array}{l}\text { 5. Economics } \\
\text { dominant sector is farming and } \\
\text { residential construction: some } \\
\text { service and industrial }\end{array}$ & provide job opportunities & $\begin{array}{l}\text { specification of job type and } \\
\text { preference to local residents; } \\
\text { will employment opportunities go } \\
\text { to residents or will professionals } \\
\text { be transferred }\end{array}$ \\
\hline $\begin{array}{l}\text { 6. Public Fiscal Structure } \\
\text { revenue source is primarily from } \\
\text { property taxes; some industrial } \\
\text { and manufacturing; budgetary } \\
\text { priorities include school, public } \\
\text { facilities and road improvements; } \\
\text { residents provide for individual } \\
\text { septic systems and well water }\end{array}$ & subsidized by casino revenues & $\begin{array}{l}\text { IGRA legislation provides for } \\
\text { sovereign nation status, therefore } \\
\text { waives tax burden; compact } \\
\text { negotiations set schedule for } \\
\text { compensation and is subject to } \\
\text { change }\end{array}$ \\
\hline
\end{tabular}




\section{Opportunities and Constraints Associated with the Substantive Issue}

Literature reviews conducted by writer/planner raised additional concerns which were discussed with members of the Town Council, the Planning Board, and the Solicitor.

Findings indicated the focus on exclusively the physiological concerns of site location for gambling facilities had yielded to more recent attention and research focused on host communities and the soci-economics of casino gambling impacts. Although a summary of the literature was forwarded to the Town Council President, the planning related issues highlighted below illustrates both potential gains and losses for host communities:

- "Regional Planners Are Gridlocked By Casino Traffic." As more and more casino traffic clogs local roads, regional planners meet in Connecticut to wrestle with solutions (Norwich Bulletin. July. 1994).

- There are difficulties involved in marketing socially unacceptable products such as tobacco, alcohol, gambling, pornography, and firearms. One key element in distributing products and services that fall within this category, is to shorten the channel as much as possible. The shorter the channel, the less exposed the product is to social criticism (Marketing News, 1994)

- Tribal gaming has proven to be the single greatest opportunity to eliminate the horrendous poverty on Indian lands in the history of the federal/tribal relationship.

The Mashantucket Pequots are a model tribe, they have provided financial security and educational opportunities for the next generations of American Indians (Pequot Times, 1994). 
- "Gambling As Economic Policy: Enumerating Why losses exceed gains." Apart from the social harm that it causes, gambling would be just another inconsequential, low-technology business earning ordinary profits and exhibiting easy entry and exit. It is a logical impossibility for every area to win at the others' expense when gambling is present in every region. For the nation as a whole, there will be no net economic development from the spread of gambling, but there will be the creation of a new social problem and the social costs that entails. From a national perspective, the sole benefit of gambling is that it is an additional form of entertainment for the subset users who gamble recreationally and can do so without harming themselves or others. The cost-benefit question is whether another form of entertainment is needed whose social costs are equal to an additional recession every decade (Illinois Business Review. Spring, 1995).

- "Casino: A Bane and a Bonanza". Nobody realized the effects of Indian sovereignty on eastern Connecticut until there was this multimillion-dollar casino rising above the trees. The Mashantucket Pequots ${ }^{\circ}$ Foxwoods casino has forever changed the balance of power and the economy of southeastern Connecticut. Where once there was a wooded reservation, there is now a multi-million dollar casino and entertainment complex employing more than 9,000 people, with an estimated 35,000 patrons per day, tripling traffic on local roads. And it happened so quickly, leaving residents reeling from the impacts. But what if we knew then what we know now? How could the region have better braced for the dramatic impact of Foxwoods casino and Pequot sovereignty? (Norwich Bulletin, 1994). The Norwich Bulletin. with sister paper, The 
Dessert Sun of Palm Springs, California held a reader forum to discuss precisely that: hindsight. Three topics kept surfacing during the roundtable discussion with the randomly chosen group of 11 readers. 1) surprise at the Pequots' success, 2) concern over the lack of planning and communication, and 3) distress of strained relations between residents and tribal members. Taken by surprise, residents living near the casino said part of the problem rests with residents' attitudes toward the Pequots. Before the bingo hall, we did not give the Pequots much thought, we should have been involved from the beginning. None of the local banks would help fund their projects: they never really accepted the Pequots or had faith in their plans. Now the Pequots use only international banks and local banks are kicking themselves. Poor communication -- relations between Ledyard, Preston, North Stonington and the tribe are more strained today then they have ever been. At the heart of the matter is the issue of sovereignty and land acquisition. Residents have been in an angry panic ever since the Pequots expressed interest last year in placing into trust up to 7,600 acres of land outside their congressionally designated reservation. Annexed land is free of state and local ordinances and taxes. The tribe and the three towns are now working with professional mediators to help settle differences, but there is too little communication and it came too late, now they are in the driver's seat. Poor planning -- Residents agreed that poor communication led to a virtual dearth of planning for the impact of the casino. Many were frustrated the towns were not given the opportunity to adequately plan for the changes wrought by Foxwoods. Nobody talked about the traffic until it was too late. Compounding the problem is how ill-equipped the towns 
are to study the impacts; we are dealing mostly with volunteers in North Stonington who are learning as they go along (Norwhich Bulletin, August 14, 1994).

- In 1993, 70 million Americans visited ballparks, but 92 million went to casinos. In 1994 , they dropped a prodigious $\$ 400$ billion in total wagers, ranging from poker, and slot machines, to horse tracks and lotteries. The gaming industry creamed off around $\$ 37.5$ billion in revenues (Fortune, March, 1995).

Widespread growth in legal gaming has been driven by two factors: enormous pentup demand for gambling-style entertainment and public officials desperate for new sources of revenue. Nearly $\$ 330$ billion was wagered in 1992 , an $8.4 \%$ increase over the previous year. Leading the increases were casinos on riverboats and Indian reservations. One operator said competition is all the other forms of entertainment in the area. not other casinos (Marketing News. June, 1994).

- "Can't Tax What You Can't See" The amount of money involved in criminal activity, and the subsequent tax revenue that is lost is of interest to both economists and policy makers (Fedgazette, April, 1994).

- "Gaming Industry: A Winning Strategy." Today, the gaming industry encompasses land-based casinos in more than ten states, Indian reservation gaming in 17 states, dockside or riverboat casinos approved for six states, and lotteries in 37 states, the District of Columbia and Puerto Rico. The industry's handle in 1992 soared to $\$ 330$ billion, a stunning $26 \%$ increase in only a decade. The same year also had record profits of $\$ 26.7$ billion for the industry. As gaming opportunities abound, so do potential returns for investors. A recovering economy, the demand for gaming in new 
jurisdictions, and the public's growing fascination with the fun and excitement of gaming, suggest that the industry will be a winner for years to come (Institutional Investor, Feb. 1994).

- "Foxwoods Jobs Halted Free-Fall." Foxwoods jobs halted the free-fall of housing prices and unemployment caused by the layoffs associated with Electric Boat of Groton, Connecticut. Base pay at Foxwoods may not approach Electric Boat wages, but benefits and tips can add up to a healthy package. For the region, it is perceived by many as an economic success story. Since opening in 1992, the casino has hired 9200 people, making it the region's second largest employer. Many of the employees report they are earning more that they did at their previous jobs. As for benefits, the casino may be second to none in the region because they offer all employees and their families. free and comprehensive health care through its own HMO health plan. Nonemergency visits to the doctor cost ten dollars, and all hospital stays, no matter how extensive, are at no cost. Like many twenty-four hour businesses, retaining permanent employees for long periods is a problem, and the casino believes offering a generous benefits package is one way of countering that trend (Norwich Bulletin. August, 1994).

- "Teenage Gambling." In areas with casino gambling, about half of all high school students gamble, and some studies have found that as many as $86 \%$ have gambled at least once in the past twelve months. Casino owners understand the addictive nature of teens and adolescents. Unfortunately, they use this knowledge to their advantage. For example. you have state governments promoting lotteries. The message they are 
conveying is that gambling is not a vice, but a normal form of entertainment. This should raise serious questions about the development of "family-theme park" casinos. This will not only capture the parents' money in the short term, it also desensitizes children to the casino environment and prepares them for gambling in the future (in Waldon, 1994). 


\section{SECTION TWO}

\section{THE OUTLOOK ON GAMBLING}

\section{IN WEST GREENWICH, AS PERCEIVED BY ITS STAKEHOLDERS}

\section{Narragansett Indian Tribal Nation:}

Under terms of the 1988 Federal Indian Gaming Regulatory Act (IGRA) legislation, the Narragansetts, along with many Indian nations, argue that gambling has afforded them unprecedented opportunities for employment, enhanced services for tribal members and provided for immense economic growth. They believe that Indian sponsored gambling offers a chance to bring people of different backgrounds together in an environment of respect and acceptance.

The Narragansett Indian Tribe, like Native Americans across the county, hoped to reverse the long history of suffering brought about by ignorance, poverty, and exclusion from the mainstream economy in Rhode Island. Stressing a rich heritage and tribal folklore, along with their respect for the environment, the tribe proposed to build a gambling casino on land (in West Greenwich) which was not contiguous with their reservation located in Charlestown, Rhode Island. Narragansett Tribal leaders respect the success of Foxwoods Casino and Resort sponsored by the Mashantucket Pequot Nation in Ledyard, Connecticut. Leaders of the Pequot Tribe have used profits generated from the casino to provide jobs, housing, education and a secure financial future for many of their tribal members. More than 150 Indian casinos are now operating nationwide and Indian sponsored gambling has become a $\$ 4$ billion a year industry (Goodman, 1994). The 
Narragansetts expect that gambling which they sponsor in their native state will afford them an opportunity for prosperity and economic independence.

\section{Indian Gaming Regulatory Act of 1988 (IGRA):}

This federal legislation sets out rules for casino compact negotiations between Native American Indian tribes and host communities. The Act creates three classes of gaming. Class I is traditional games and is not subject to oversight by any entity other than the tribe. Class II gaming includes bingo and related games. Class III gaming includes casino-type games, pari-mutuel wagering, lotteries and video terminals. Class III gaming can only be conducted after an agreement, as a compact, is reached between a tribe and a state. The center piece of the bill requires tribes to negotiate with respective states before commencement of any on-reservation gambling, including casinos. The law also requires states to negotiate in good faith and guarantees tribes may file suit against a state in Federal court if a state fails to comply. Another section of the legislation allows both the tribes and the host community to seek intervention by the Secretary of the Interior and the Bureau of Indian Affairs. The Narragansett Indian tribe cited IGRA and wanted casino style gambling based on legal video wagering which was already allowed in Newport and Lincoln, Rhode Island. The Narragansett Tribe voiced concerns that Rhode Island state representatives discriminated against them, and argued they will continue to pursue their legal rights in the Federal courts.

\section{Capital Gaming International Incorporated:}

This New Jersey based company hoped to expand its business opportunities into the state of Rhode Island. It is the United State's largest manager of Indian sponsored gaming. and 
has contracts with eight native American Indian tribes operating in Arizona, California, New York, Oregon and Washington. The company financed over one million dollars in advertising campaigns to promote the West Greenwich casino sponsored by the Narragansett Indian Tribe.

\section{GTECH World Headquarters:}

This company, located in West Greenwich, was a joint venture partner with Capital Gaming in the casino proposal signed by Governor Sundlun. The company saw the Narragansett Indian casino as a business expansion opportunity; declared its financial backing: and agreed to supply all the casino gaming equipment to the Narragansett Indian Tribe.

\section{THE STATE LEVEL}

\section{Governor Sundlun:}

Sundlun believed that if Rhode Island did not spend the money and build a gambling casino within the state, all the potential profits from gaming revenues would be lost to states elsewhere in New England. He said West Greenwich was officially the preferred site for the Indian sponsored casino, and he guaranteed "exclusivity" to the Narragansett Indian Tribe. He was not concerned about public criticism and did not feel the compact would jeopardize his chances for re-election.

\section{Governor-elect Almond:}

During his campaign for state governor, Almond declared that any casino negotiations would include only the games currently allowed in Rhode Island which include jai alai, dog racing, keno, daily numbers and video slots. Illegal games include blackjack, roulette 
and poker or casino style slot machines. Almond was a self-proclaimed opponent to gambling and joined the Rhode Island Attorney General's office in their suits against both the Narragansett Indian Tribe and Governor Sundlun.

\section{State Attorney General (AG):}

This office provides the state's legal defense. Prior to the Governor's compact which cited West Greenwich, the AG's office filed a legal suit against the Narragansett Indian Tribe. The basis of the suit argued that IGRA regulations for sovereignty did not apply to the Narragansett Indian tribe and therefore, Governor Sundlun could not legally negotiate for gaming with them. Later, a court determination declared IGRA was applicable, but only to Narragansett reservation land in Charlestown. Disregarding these suits, meetings between Governor Sundlun and the Narragansett Indian Tribe began in July, 1994. Prior to Sundlun confidentially signing the compact with the Narragansetts, the governor contacted the AG's office for a legal opinion to his pending arrangement with the Narragansetts. The AG's office issued an advisory opinion and warned against compact negotiations without legislative and/or voter approval.

\section{THE COMMUNITY LEVEL}

\section{Town Council and Solicitors:}

Members of the Town Council, along with the town's solicitor, rejected the Governor's compact with the Narragansetts and confidentially met with developers to negotiate under a separate town compact. Fueled by pressure from local voters to act swiftly, (before the election) these town leaders agreed to private meetings with the Narragansett Indian Tribe to negotiate a "community friendly compact" for West Greenwich. 


\section{Planning Board:}

As determined by records from discussions during the October, 1994, General Meeting, Planning Board members asserted it was not their responsibility to discuss and/or act in any manner on the proposed gambling initiative issue. In addition, the members stated they would take no action unless a formal request was issued from the Town Council.

\section{Citizen Groups}

Nearly the entire community became involved in this highly public, emotionally charged controversy. A huge chasm divided the two sides in the debate. Both factions promoted impressive studies and expert opinion in the hopes of swaying voting residents to see their point of view.

\section{Proponents:}

There was widespread support for the proposed casino gambling initiative among groups of long time residents. Many of these local citizens felt burdened by the recent growth of the town which resulted in increased property taxes, and caused them personal hardship. Many of these same residents believed the proposed casino would help decrease tax burdens. subsidize municipal revenues and pay for expansion of town services.

\section{Opponents:}

As vocal advocates for more public participation, theses citizens were angry that the West Greenwich proposal was unjustly "thrust upon them", first by the Governor and then by their own locally elected officials. 


\section{Residents Against Gambling Establishments (RAGE):}

Representing the most outspoken sector of the population, this group of primarily West Greenwich residents was described by the mainstream media as a loose-knit, grass roots community organization, who attempted to persuade undecided citizens to register and vote against the gambling initiative. Many of these residents perceived the negative impacts of similar communities that welcomed casino gambling. With its close proximity to Connecticut, many West Greenwich residents were aware of and feared similar impacts caused by the Mashantucket Pequot Foxwoods Resort Casino in Ledyard, Connecticut. Data showed that since Foxwoods opened, an estimated 350,000 patrons per day visited the site. The traffic on local roads leading to the facility had tripled, causing increased congestion and noise. West Greenwich residents also feared school buses would pass the gaming facility a minimum of twice daily, and expose young children to gambling activities. Another source of concern was the issue of sovereignty and future land acquisition. Residents feared that more land would be lost from the tax rolls and the remaining land would become a commercial strip that was out of scale with the town's scenic rural landscape.

\section{Adjoining Communities:}

With gaming initiatives on many local ballots, cities and towns throughout Rhode Island were engaged in dialogue about casino gambling. In the town of Coventry, which borders West Greenwich, the elected town officials offered public forums on the proposed gambling casino. Speakers at the forums included Bill Haase, the town planner for Ledyard, Connecticut. Haase spoke of impacts from increased development in his town 
since the Foxwoods Casino was built three years ago. He also discussed the broad range of social disruption to the lives of residents in the three communities abutting the facility. The purpose for the public information forums, according to Coventry Town Council President Kiley, was to learn how secondary development, the building of restaurants, motels and shops have affected Ledyard, and therefore similarly, could affect Coventry. Similar meetings took place in communities across Rhode Island and Massachusetts. 


\section{SECTION THREE}

\section{CHRONOLOGY OF EVENTS}

On the morning of August 29, 1994, the governor for the state of Rhode Island and Providence Plantations, Bruce G. Sundlun announced an agreement had been reached with the Narragansett Indian Tribe to build an Indian sponsored gambling casino. The agreement stated that Capital Gaming International Incorporated, of Atlantic City, New Jersey, was set to build a 120,000 square foot casino with three thousand slot machines and a 24 hour liquor license on a 300 acre site off Route 95 at Exit 5, in the

town of West Greenwich. Capital Gaming would also manage the Indian sponsored casino. The state/Indian compact would become effective subject to the passage of both a local referendum for West Greenwich, as well as a state-wide referendum provided for under Rhode Island State Law (R.I.G.L. ss 41-9-1 et seq).

However, before West Greenwich residents could vote on a referendum, the Town Council was required to place the gambling casino initiative question on the local ballot The state deadline for ballot questions to be added was nine weeks from the date of the tendered proposal. 


\section{Narrative of Daily Activities and Events}

\section{Monday August 29:}

- Listening to the morning radio broadcast, writer/planner learned of the casino gambling compact while driving to work. Upon arrival at the West Greenwich Planning office, writer/planner immediately telephoned the Town Council President to inquire about the compact and to solicit information connected with the official protocols and position of the town. Inquiries from local residents and the media clogged every incoming telephone line. Town Council President stated that he would delay comments until an official announcement was made from the Governor's office scheduled for three o' clock that afternoon.

- Writer/planner subsequently made a series of telephone calls and first contacted the principal town planner in the adjacent town of Coventry, to discuss possible information sources on the issue of gambling. He referenced principal town planner Bill Haase in Ledyard. Connecticut, host community to Foxwoods Casino and Resort as an experienced resource.

- Writer /planner contacted Haase and apprised him of the circumstances. He immediately offered condolences and went on to discuss planning issues that have created significant and ongoing problems for Ledyard. Discussions focused on similarities between West Greenwich and Ledyard. Subsequent conversations with him were helpful and informative. He provided sources for further information about planning in communities which have experienced controversial land development projects. In addition. he offered to arrange a meeting with Ledyard selectmen and 
West Greenwich town council representatives. He also forwarded a current traffic study conducted by his office, which focused on local arterial roads and the impacts in Ledyard. Highlights of the study indicated interstate highway standards, which are usually cited in impact studies for host communities, are not applicable to host communities in small towns located off the highways. He added that traffic congestion and road maintenance were continuous problems, and Ledyard had received little to no state assistant for these problems. He then referenced Ledyard's legal counsel, Don Baur, as a valuable resource for issues of Indian sponsored gaming.

- Writer/planner telephoned attorney Don Baur, in Washington, DC and summarized the situation in West Greenwich. Writer/planner expressed concern about the short time frame within which official town decisions had to be made, and solicited his opinion on legal strategies available to the town. He replied that he had lengthy experience with the Bureau of Indian Affairs (BIA), the Department of Interior. and currently spent much of his professional time representing four communities which border the Mashantucket Pequot Foxwoods Casino in Ledyard, Connecticut. Baur felt that West Greenwich had numerous legal rights that deserved close examination, these issues included:

1) the proposed site in West Greenwich was not contiguous with the Narragansett Reservation land in Charlestown, and therefore, was not subject to sovereignty statute in the land trust acquisition process outlined in IGRA legislation;

2) Governor Sundlun did not have legal authority to bind the compact without legislative approval; 
3) the BIA had certain criteria to determine the respective needs of tribes and host communities, therefore, if West Greenwich elected officials negotiated with the Narragansetts prior to the state election, the town's future leverage to appeal would be seriously weakened; and

4) town decision makers should consider all possible options available to them under the IGRA legislation and not act hastily to compact with the developers. The conversation compelled writer/planner to urge caution the Town Council President, and suggested an open information collection and dissemination process be implemented without delay.

\section{August 30:}

No feedback was received from the Town Council President, therefore, writer/planner proceeded to survey other professional planning colleagues with experience in Rhode Island community's. Colleagues included: Deborah Perry, the planner for Charlestown, which is the current site of the Narragansett Indian reservation; Joseph Lombardo, planner and consultant for Hopkinton and Richmond; and Tom Mitchell. Executive Director, Alton Jones Camp and Conference Center in West Greenwich. Each indicated helpful suggestions to add to the data collection process, and advocated an impact study be included in writer/planner's recommendations to elected decision makers.

- Later that day, John Mullin, a professor at the University of Massachusetts-Amherst and a leading authority of New England economic development was contacted. Telephone discussions focused on community planning issues associated with 
gambling establishments. He in turn referenced Robert Goodman for further information on gambling, economic development and host communities.

Writer/planner was familiar with Goodman's work in planning research, and in particular, his gambling study in Massachusetts.

- Contact was made and during the conversation, Goodman suggested that writer/planner propose options to the West Greenwich elected officials. One alternative that Goodman considered the most practicable and effective included a public information conference to be held as soon as possible. In order to lessen the burden to the town, the public forum could be funded and sponsored by the Rhode Island Department of Economic Development. In addition, he suggested that the proposed developers, Capital Gaming International, was probably not aware of the concept of home rule charter in New England. Most gaming enterprise representatives were accustomed to dealing with county bureaucrats and were not concerned about the skepticism of many local residents. At the end of our conversation. he offered to be available at any time for further assistance.

- One of the last people contacted that day was Trenton Wright, principal owner of Community and Business Strategies. Inc. As a planning consultant working in Willimantic, Connecticut, he was a recognized authority on economic development and locally unacceptable land uses (LULU's). His most recent experience included agreement negotiations between a tire burning plant and a local host community. He discussed potential considerations for West Greenwich, should the proposed casino be 
approved, and added a variety of impacts be reviewed by West Greenwich decision makers which included:

1) the routing of traffic and maintenance impacts on local roads;

2) the issue of employment and jobs--what are the types of occupations and wages paid; and will there be local hiring and how much?

3) legal options for the town should include the right to arbitration prior to litigation; and,

4) the developers should be required to finance and supply the town with transportation and environmental impact studies.

- Unable to confirm a meeting that included West Greenwich officials, writer/planner met with Wright at the West Greenwich Town Hall to discuss potential strategies.

- In an attempt to confirm the town`s legal position, writer/planner spoke with representatives from both the Governor's and State Attorney General's offices. Governor Sundlun's chief legal counsel and spokesperson Elizabeth Murdock Meyers, said that the Governor's administration had been meeting regularly with the Narragansett Indian Tribe since July, 1994, and those proceedings were valid Assistant Counsel Alan Shaw of the U. S. Attorney General's office maintained that one or both of the following was necessary for Governor Sundlun's West Greenwich compact to be constitutionally sound: 1.) General Assembly consent, and 2.) a majority vote from the state, as well as host community constituents. 


\section{August 31:}

Based upon notes of these conversations, writer/planner summarized the data collected and mailed the information to each member of the Town Council and Planning Board. In the packet sent to the Town Council President, writer/planner requested him to contact the planning office, as he was increasingly difficult to reach by telephone.

- Prior to mailing this information, writer/planner telephoned Howard Foster, Ph.D. at URI’s Community Planning and Area Development to familiarize him with the situation and ask for his views. Writer/planner expressed concern about how to address the inaction of the elected officials and the demands of local residents. Discussions then focused on professional and ethical dilemmas. Writer/planner did not intend to jeopardize the CPAD department's reputation, nor misrepresent the internship position by "doing the wrong thing". Foster affirmed writer/planner's actions were within boundaries of professional conduct and further advised he would be available for participation in a non-partisan panel discussion. We also discussed options for panel participants, locations, and dates to propose to West Greenwich decision makers.

- A teacher at the West Greenwich junior/senior high school telephoned writer/planner to request assistance and stated:

1) student reporters for the school publication were interested in learning more about the West Greenwich gambling casino initiative; 
2) students were unable to get detailed information about the local compact between Town Council member and the Narragansett Indian Tribe; and,

3) students felt their voting parents/guardians were deprived of "official" information on issues proposed by the gambling casino compact.

Further discussions examined opportunities such as a school sponsored assembly with parents and the general public invited to attend. The format could be a "point /counter point" discussion which would explore issues of gambling, identify local sentiments on the issue, and identify potential impacts to the town. We also discussed a format where the students could interview various decision makers and the developers about the proposal. Writer/planner informed the teacher that the discussion would be conveyed to the Town Council and other elected officials.

- Before leaving the office that day, Town Council President advised planning office to postpone any activity on public meetings.

\section{September 1:}

- Town Council members held their monthly General Meeting in the Exeter-West Greenwich Regional Junior Senior High School. The purpose of the meeting was to discuss whether or not West Greenwich residents should be allowed the opportunity to vote on the proposed casino compact. The Town Council President opened the meeting and stated representatives for the gambling casino developers and the Narragansett Indian Tribe were scheduled to address the crowd.

- Writer/planner met with West Greenwich town solicitors to provide them information which had been compiled to date; and also met with Capital Gaming International 
representatives who were accompanying Lloyd Wilcox, the Narragansett Tribal spokesperson.

- During his address, Wilcox assured town residents that the Narragansetts would build a facility comparable in quality and style to Foxwoods Casino and Resort in Ledyard, Connecticut. The crowd became boisterous and before Wilcox could finish his comments, angry residents shouted angry protests at the "arrogant presence of the developers, as well as the Governor's gall at pushing the compact down our throats".

- The Town Council was not able to quiet the crowd, however, before adjourning the meeting, they did vote to approve a local referendum on the November ballot.

- Writer/planner obtained a copy of Governor Sundlun's compact, reviewed the text, and later that week forwarded comments to the town council members (For summary of comments, see Figure 5. in Appendix)

- The following day writer/planner continued to hold meetings with town Planning Board members. Discussions focused on identifying workable solutions which addressed the tensions, and sense confusion that overshadowed the situation.

- In addition to the strained relationship with elected officials, writer/planner noticed the business atmosphere at the municipal offices, which was generally calm and orderly, had become chaotic and fretful. Many employees were overwhelmed by endless inquiries from residents and attention from local and international media; and preferred the entire ordeal "just end so the town could get back to normal".

- Writer/planner sympathized with their anxiety: cautioned them about the possibilities of unprecedented and fundamental change to the "normal" way of life if the casino 
initiative was implemented and discussed the need to publicly inform residents about the opportunities and the constraints of such a proposal. While one group of employees feared grave social and environmental disruption, others openly welcomed the changes from a casino gambling facility and dismissed the situation as "nothing to get worked up over".

- During the Planning Board's September meeting, members did not hold discussions about residents concerns of the proposed casino. However, casual conversation among members of the Board revealed some dissension between members who questioned the role they should play in the gambling casino issue, and those who expressed confidence in the Town Council's abilities. Further, some members stated they looked forward to job opportunities with the gambling casino-- whether managerial or service oriented - they favored expanded employment possibilities

\section{September 11:}

- The Town Council met for the Regular Monthly meeting and approved the gambling casino initiative be included on the November election ballot. After the meeting, Town Council President stated he would be in charge of the casino project and suggested writer/planner focus on "other administrative procedures" in the planning office.

Writer/planner agreed to suspend further research on the casino project, but could not ignore the many public inquiries received by the planning office. Therefore, a resource file was established at the town's free library, to which to refer callers. The Town Council President was informed of this decision and made no objection. 


\section{September 16:}

- Opponents of the proposed West Greenwich casino gathered to form an advocacy group: Residents Against Gambling Establishments (RAGE). The group's leader, Ellen Sidbury contacted the planning office to express concern over the "clandestine" manner in which elected town officials handled the gambling casino issue, and said that people did not want to be seen with her or give her their names for fear of reprisals from "higher ups". In addition, she expressed curiosity over the closed door policy that prevailed since the debut of the issue--first the Governor and now locally elected town officials continued to exclude or limit public access to information.

\section{September 21:}

- Writer/planner learned of the first meeting to be held between West Greenwich Town Council and Narragansett Tribal Council members, and contacted the town solicitor for specific details.

- Solicitor stated the meeting would be broadcast over the TCI Cable Television network. and the issues to be discussed during the meeting agenda included projected traffic counts and transportation; disruption to the scenic landscape; the handling of water and waste; and future land acquisition policies.

- Writer/planner inquired as to how to respond to similar issues and concerns which continued to be directed to the planning office, and whether or not town officials had considered any options which would include more public participation

- Solicitor responded that nothing was accomplished during previous public meetings. and given the complexity of the situation, "only chaos would result from a public 
process; the telecast meetings should be sufficient; and an local information center was being opened within the next few days".

- Writer/planner expressed enthusiasm and inquired about who the sponsor was -Solicitor's reply -- the "Narragansett Indians of course".

- Writer/planner asked about who would represent the "other side"; provide technical analysis of the proposal; and respond to concerns expressed by residents?

- Solicitor said all inquiries should be directed to him or the Town Council President.

\section{Electronic Town Meeting Broadcasts}

Following are writer/planner's notes of town's first "telecast" meeting:

- Indian Tribal spokesperson, Lloyd Wilcox assured the viewing public of the Narragansett's interest in preserving the forested landscape and the natural environment and stated, "the trees are our grandfathers... we have tremendous respect for the land of our ancestors."

- Town Council President, expressed concern about the tribe's intentions for future expansion of Indian holdings beyond the proposed 300 acre site; Wilcox said the proposed acreage should be adequate, and added "if property owners approached them, the Narragansetts would consider any offers."

- Tribal Councilman Byron Brown spoke about the pride of the Narragansett Indians and how they have tremendous respect for the natural environment. He added they were pleased with the rural setting in West Greenwich, and would do their best to keep the property clean and treed and; commercial strip development along Victory Highway would not be promoted. 
- Town Council President encouraged the Tribe to sponsor a public information forum to address the concerns of residents, and stated, "at previous meetings, too many people screamed and hollered so much that we (the Council) could not get anything done".

In subsequent conversations with Town Council President, writer/planner expressed concerns about the problematic nature of their private compact negotiations, as well as the implicit assumptions of meeting formats with TCI Cable telecast:

1. When Town Council members elected to participate in compact negotiations, they assumed the gambling casino proposal was officially approved for West Greenwich the Council acted as though it was a done deal;

2. The Council assumed residents owned and/or had access to television broadcast serviced by $\mathrm{TCI}$ cable, and;

3. The Council assumed residents were only interested in a unilateral information dissemination process, and were satisfied to watch and not participate in the discussions.

\section{Last Weeks of September}

- Many municipal employees who worked at the Town Hall during the evening hours complained they were unable to view the meetings; the Town Council President assured a video copy of all meetings would be made available.

- During telephone conversations with writer/planner, the town's Council members and Solicitors justified the private and hasty nature of their compact negotiations and stated "certain events had dictated immediate action". Town Council President said 
he had spent close to twenty-four hours a day on the gambling casino compact negotiations; he felt overwhelmed by the worldwide media attention and the incessant inquiries from the local residents; the scrutiny from other municipal representatives, and; his family's livelihood had been seriously disrupted.

- In an attempt to stimulate conversation and diffuse the unresponsive attitude of elected officials, writer/planner acknowledged the sense of urgency and personal pressures cited by the elected officials, and went on to discuss successful options utilized by communities in similar situations. One example suggested options utilized to engage elected officials and local residents in various public decision making processes.

- Options proposed to the West Greenwich elected officials included:

1) Together with the town officials, the planning office could create a select committee of various residents and other experts with the charge of managing the gambling casino issue:

2) Create an advisory group whereby the planning office solicit assistance from professional Planning colleagues. Universities and Colleges, chambers of commerce: local and state representatives; Rhode Island Department of Transportation, Historic Preservation Societies, Department of Economic Development, Department of Environmental Management; and any other agencies identified as potential resources;

3) if municipal funds allow, contract for a consultant to facilitate public information forums. 


\section{Discrepancies In Previously Implemented Planning Processes}

Writer/planner had worked with the previous West Greenwich Town Planner, Ann Skiver, and felt procedures implemented through the planning office under Skiver's guidance were representative of fair public participation policies. Writer/planner contacted Skiver to ask her view of the casino compact situation. Skiver was confused and angered by the inaction of the Town Council and suggested writer/planner initiate dialogue with the Planning Board. Writer/planner researched municipal archives and official planning documents; and based upon the data, recommended to Planning Board Vice-Chair that the casino proposal be included in the October meeting agenda and referenced the Land Use and Planning Enabling Act, "Other duties of a planning board or commission:

(a) A planning board or commission established under the provisions of this chapter shall make studies and prepare plans and reports on the needs and resources of the community with reference to its physical, economic, and social growth and development as affecting the health, safety, morals, and general welfare of the people. The studies. plans. and reports shall concern but shall not necessarily be limited to the following:...(e) a planning hoard or commission shall have authority to call upon other departments. boards, and committees of the city or town and upon regional. state, and federal agencies for information and assistance necessary to the performance of its duties and shall cooperate with the city or town. regional, state, and federal agencies on matters of community, regional, and state planning and development (Division of Planning, Rhode Island Department of Administration. 1992. Handbook Number 7: 45-22-7). 


\section{OCTOBER}

Prior to the start of the Planning Board's General Meeting of October 3, 1994, the local television and radio media had set up cameras and microphones in the meeting hall.

- Writer/planner sensed the Planning Board members were restless and agitated. The meeting followed the customary agenda with discussions focused on zoning appeals, site plan reviews and other matters, until the Planning Board Chair called attention to agenda item listed under New Business: 1) Discussion of proposed Narragansett Indian Tribe/Capitol Gaming International casino.

- After a few moments of conversation among themselves, various Board members asked who had approved the agenda item, and why.

- Writer/planner asserted consultation between she and other board members indicated the need to publicly discuss impacts of the proposed gambling casino. and expressed additional concerns that influenced the decision to initiate discussion:

1. the town did not have a comprehensive community plan that post dated 1965;

2. the updated zoning ordinance was not approved and:

3. locally elected of ficials resisted open discussion about potential impacts of the casino gambling development proposal

The Planning Board Chair responded that no action would be taken until the Town Council request assistance from the planning board. The meeting ended and there was no further discussion. 


\section{Political Pressure on Professional Judgment}

\section{October 4:}

- The following morning, the council president telephoned the planning office. He expressed anger about telephone calls he had received concerning the casino gambling proposal that was placed on the Planning Board Meeting Agenda. He stated that clearance from him was necessary for future discussion items. Writer/planner inquired about previous policy and advised she had not been challenged on agenda protocol in the past; why now? He replied that planner was to deal with the sand and gravel permitting problem and leave the casino situation to him and the solicitors.

- The local clerk of canvassers informed planning office that voter registration was brisk and more than ten percent of town's 3083 voters had registered over the last few weeks.

- Approximately 3700 West Greenwich residents received a video cassette through the U.S. Postal Service. The advertising film, sponsored by Capital Gaming International. illustrated various Native American rituals characteristic of the Narragansett Indian Tribe and their heritage in Rhode Island.

- Writer/planner visited the Narragansett Indian Tribal Information Center which featured native pictorial displays of customs and ceremonies, a West Greenwich site plan and casino employment applications (See Appendix B). Writer/planner inquired about more specific details of the proposed gaming facility; the demographics of the tribe; whether there was a schematic blue print or scaled model of the casino; and where to find out more about the specifications of the proposed facility. The public 
information center representatives said they were hired by Capital Gaming International. and were photographic and cultural experts of the Narragansett Indian Tribal Nation. They did not have specific information about the site specifications, only job applications for any resident that wished to apply for a position with the proposed facility.

\section{October 12:}

- Members of the Narragansett Indian Tribe, along with representatives from Capital Gaming International offered the first public viewing of West Greenwich casino gambling site; a large group of residents gathered outside to voice their opposition to the casino gambling initiative.

\section{October 13:}

- An announcement was issued from the town clerk's office: "The West Greenwich Town Council, at its October 12, 1994 meeting voted to hire William R. Lepak to work in the Planning Department ...21 hours per week for 60 days on an interim basis. The effective date of hire is October 17, 1994" (Interoffice Memorandum. 1994).

- Lepak graduated from the University of Rhode Island, Community Planning and Area Development (CPAD), and had planning experience, most notably with the development of the Emerald Square Mall in Massachusetts.

- Neither Lepak nor writer/planner was made aware of the other's employment status; writer/planner inquired about employment status; Town Council President replied writer/planner was still considered one of the interim town planners, and looked forward to working with both planners. 


\section{October 16 -17:}

- Writer/planner participated in the annual conference in Newport, Rhode Island sponsored by the American Planning Association, and attended a session on "Gambling Casinos and Gaming as Economic Development Strategies". The session presented a panel discussion with gaming enterprise representatives and local economic development experts. The panel was followed by a question and answer period from the audience. The forum offered a wide variety of perspectives on the opportunities and constraints offered by gaming and especially, gambling casinos.

\section{October 20:}

- The Town Council President announced an agreement between the Narragansett Indian Tribe and the Town of West Greenwich had been completed. Writer/planner communicated to the Council President her concerns about the long range nature of the compact. Any agreement that would govern the lives of residents

- Narragansett Indian Tribe and Capital Gaming mailed out a second video cassette to residents of West Greenwich. The subject matter included environmental awareness and advertisements for employment at "the future Narragansett Gambling Casino".

Writer/planner viewed video cassette and communicated to Council and Board members concerns about the lack of substantive information, and that residents expressed similar frustrations to the planning office. 


\section{NOVEMBER:}

- During the first week, writer/planner continued to train with the new planner; prepared for the next Planning Board meeting; and shared responsibility to respond to telephone inquiries from residents and the media about the West Greenwich gambling casino initiative.

- Writer/planner did not attend the November Planning Board General Meeting due to scheduling conflicts with graduate school.

\section{November 7:}

Five communities asked for voter approval to host a gambling casino in their locale:

Providence, Pawtucket, Lincoln. Coventry (casino and golf course resort complex) and West Greenwich.

- After West Greenwich Town Council members announced a compact had been made between the Narragansett Indian Tribe and the town, they declared they had done their part to protect the town and would wait for voter outcome.

- The local journalists predicted a real "cliffhanger" on election day. 


\section{CHAPTER FOUR: FINDINGS}

Information is a source of power in the planning process...Whether or not power corrupts, the lack of power surely frustrates. Planners know this only too well. They often feel overwhelmed by the exercise of private economic power, or by politics, or by both (Forester, 1982). 


\section{Introduction}

The primary focus of this project is to examine the values for analyzing a set of decisions which led to actions made in response to a controversial community issue. More specifically, this chapter will utilize the theoretical framework discussed in Chapter Two to describe how and why the writer/planner responded to a situation which presented professional and ethical concerns during the time of study. The findings reflect research undertaken to provide insight into the dynamics between the writer/planner's observable actions, that is the professional planning activities; and the non-observable personal views, thoughts, feelings, and value commitments during the time of study.

Writer/planner's professional and ethical principles conflicted with those of other participants in the case example. More specifically, the issues of conflict related to principles of loyalty, accountability, and serving the public interest. The descriptive steps in this section include discussions on:

1. defining the issues; describing the contextual characteristics of the situations

2. analyzing the actions and types of planning related activities; describing how issues were perceived and articulated by writer/planner; and participants involved

3. articulating specific contextual and personal factors that influenced writer/planner's behavior; examining why course of action was justified

4. measuring the consequences or implications

The summary of the discussions are illustrated in the following table. 
Table 3. Professional Planning Activities and Subsequent Details

\begin{tabular}{|c|c|c|c|}
\hline Scenario* & $\begin{array}{l}\text { Ethical Concern+ } \\
\text { and Issue } \\
\text { Benefiting } \\
\text { (a) }\end{array}$ & $\begin{array}{l}\text { Tactics } \\
\text { (b) }\end{array}$ & $\begin{array}{c}\text { Outcomes - Effects } \\
\text { of Tactics } \\
\text { (c) }\end{array}$ \\
\hline $\begin{array}{l}\text { 1. technical data } \\
\text { reporting }\end{array}$ & $\begin{array}{l}\text { 1. obligation to } \\
\text { inform stakeholders }\end{array}$ & $\begin{array}{l}\text { 1. to inform elected } \\
\text { officials, and others } \\
\text { of potential impacts } \\
\text { of proposal }\end{array}$ & $\begin{array}{l}\text { 1. no action from } \\
\text { elected officials }\end{array}$ \\
\hline $\begin{array}{l}2 . \text { identify } \\
\text { resources and } \\
\text { propose alternatives } \\
\text { for informing the } \\
\text { public }\end{array}$ & $\begin{array}{l}\text { 2. obligation to } \\
\text { citizens and } \\
\text { commitment to a } \\
\text { participatory process } \\
\text { of decision making }\end{array}$ & $\begin{array}{l}\text { 2. pressure on } \\
\text { elected officials to } \\
\text { change or develop a } \\
\text { position }\end{array}$ & $\begin{array}{l}\text { 2. electronic town } \\
\text { meeting format } \\
\text { limited access to } \\
\text { decision making } \\
\text { process by planner } \\
\text { or constituents }\end{array}$ \\
\hline $\begin{array}{l}\text { 3. substantive issue } \\
\text { placed in Planning } \\
\text { Board's meeting } \\
\text { agenda }\end{array}$ & $\begin{array}{l}\text { 3. obligation to } \\
\text { inform constituents, } \\
\text { elected and } \\
\text { appointed officials }\end{array}$ & $\begin{array}{l}\text { 3. dramatize the } \\
\text { vulnerable status of } \\
\text { the town and the } \\
\text { long range } \\
\text { implications of no } \\
\text { action option }\end{array}$ & $\begin{array}{l}\text { 3. no action from } \\
\text { members of the } \\
\text { Planning Board }\end{array}$ \\
\hline
\end{tabular}

Source: Howe and Kaufman (1985) adapted

* scenario depicts the behavior in situation involving dilemma

+ as based upon the AICP/APA Code of Ethics

Notes: Further analysis of each action item follows the table format:

\section{(a) Ethical Concern and Issue Benefiting}

1. Ethical concern: loyalty to agency versus public interest;

Issue Benefiting: writer/planner began with straightforward objective to provide elected officials with independent, non-partisan information concerning the gambling casino proposal; the elected officials were expected to disseminate information to local constituents; however, anecdotal evidence revealed that elected officials proceeded with private meetings 
2. Ethical concern: duties of justice and a participatory decision making process Issue Benefiting: Writer/planner's objective was to stimulate public interest and citizen participation; writer/planner sought out ways to inform the community residents and public at large about the issues and consequences to the town, of the gambling development proposal; writer/planner did this without authority from Council President who disallowed public meetings; however writer/planner continued to provide information kept on file at the public library

3. Ethical concern: determining the role of the planning process in the political system Issue benefiting: Writer/planner's objective was to improve communication and facilitate an open, fair process which represented a broad range of interests

\section{Motivations To Act}

\section{(b) Tactic:}

1. Motivation was to facilitate open and fair information dissemination and decision making process; writer/planner assumed primary obligation was to provide information and independent professional advice to elected officials-- who are in turn accountable to the local constituents

2. Motivation was to acknowledge broad participation representing various stakeholders and multiple interest groups

3. Motivation was to undo static position held by the Planning Board and provide for non-partisan information and exchange of ideas on the substantive issue; writer/planner felt the Planning Board members were legally required by the state planning guidelines to discuss proposals for any land development within their community 


\section{Measuring The Consequences}

\section{(c) Outcomes:}

1. elected officials distanced themselves from writer/planner by not responding to written correspondence or telephone requests; they held private meetings with developers; electronic town meetings were used as communication; and unilateral decisions were issued from the top (elected officials) down to the public

2. public was shut out of decision making process; no collaborative process was implemented for presenting non-partisan information regarding nature of development proposal; residents felt elected and appointed officials did not provide necessary information to make informed choices

3. Planning Board refused to discuss the technical analysis of planning related impacts of the proposed development project and deferred decisions to the Town Council President

\section{Role of Planning In Politics}

As control was exerted by elected and appointed officials, the results were unpredictable. unexpected, and ultimately very frustrating for writer/planner who was committed to a participatory decision making process. This begs the question: how effective was the planner in this case example? Some theories provide insight.

Elizabeth Howe (1994), writes that a study on ethics cannot avoid the question of whether the ethical values held and acted on by planners serve the public well. The AICP/APA code is only a starting place. Career staff planners work in public bureaucracies and have input into but certainly not control over the outcomes of planning decisions. They are officially charged with serving the interest not of single individual 
clients but those of a whole community, whether a city, region, or a state. Because of this, their role is played not in some one-to-one relationship but through the political process. Planners' own ideas of what would best serve the interests of the community are only one element in a complex process of determining public policy related to development. Their expertise and professional charge relate to developing plans and recommending ways in which such plans can be implemented. The process is likely to involve considerable input by citizen groups and by developers or service providers who have a direct financial stake in the plans implementation. The final decisions are ultimately in the hands of appointed officials, such as plan commissioners or members of an executive board; and then of elected officials, such as council members.

\section{Identifying Professional Resources}

Once the issue was perceived and articulated. writer/planner elicited support from colleagues and professional group members. The table below illustrates those with whom writer/planner consulted during the time of study. 
TABLE 4. Who Writer/Planner Conferred With to Resolve Issues

\begin{tabular}{|c|c|c|}
\hline FORMAL/LEAL & $\begin{array}{c}\text { INFORMAL } \\
\text { ASSOCIATIONS }\end{array}$ & $\begin{array}{c}\text { INFORMAL } \\
\text { PROFESSIONAL } \\
\text { GROUPS }\end{array}$ \\
\hline $\begin{array}{l}\text { Town Council President; } \\
\text { Town solicitor; } \\
\text { West Greenwich Planning } \\
\text { Board members; } \\
\text { Town engineer; } \\
\text { Town Tax assessor; } \\
\text { Personnel from Board of } \\
\text { Canvasser's office }\end{array}$ & $\begin{array}{l}\text { Colleagues from graduate } \\
\text { school; } \\
\text { Interested citizen groups; } \\
\text { Town commission } \\
\text { members; Fellow municipal } \\
\text { employees in West } \\
\text { Greenwich office }\end{array}$ & $\begin{array}{l}\text { URI Alumni; } \\
\text { URI Professors; } \\
\text { President of Rhode Island } \\
\text { Chapter of APA and other } \\
\text { members; Town Planners in } \\
\text { communities neighboring } \\
\text { West Greenwich; } \\
\text { Attendees and panel } \\
\text { representatives at APA } \\
\text { Conference in Newport; } \\
\text { Professional Planners in } \\
\text { Rhode Island, } \\
\text { Massachusetts, Connecticut } \\
\text { and Colorado }\end{array}$ \\
\hline
\end{tabular}

Source: Feld and Foster (1990) adapted

\section{Justifying Course Of Action}

How did writer/planner justify the course of action in the case example? From

writer/planner's personal perspective, all three action scenarios and subsequent planning related activities allowed for some degree of discretion on writer/planner's part, that is, to act or not. The framework for examining issues such as role orientation, value commitment, orientation toward agency, citizen participation, and subsequent outcomes are summarized in the table below. 
Table 5. A Framework for Describing Ethical Issues

\begin{tabular}{|c|c|c|c|}
\hline Ethical Principle & $\begin{array}{l}\text { Classify Issue as } \\
\text { Clearly/Probably } \\
\text { an Ethical Issue } \\
\text { (a) }\end{array}$ & $\begin{array}{c}\text { Ideal Versus } \\
\text { Actual Role: Sense } \\
\text { of Dissonance } \\
\text { (b) }\end{array}$ & Images of "Role" \\
\hline \multicolumn{4}{|l|}{ Duties of Justice } \\
\hline $\begin{array}{l}\text { 1. to provide } \\
\text { independent } \\
\text { professional advice }\end{array}$ & $\begin{array}{l}\text { 1. not clear, then } \\
\text { very clear }\end{array}$ & $\begin{array}{l}\text { 1. initial } \\
\text { satisfaction; } \\
\quad \text { later frustration }\end{array}$ & $\begin{array}{l}\text { facilitator of } \\
\text { planning process } \\
\text { that is open, fair and } \\
\text { responsive to }\end{array}$ \\
\hline $\begin{array}{l}\text { 2. to be responsive } \\
\text { to the public }\end{array}$ & $\begin{array}{l}\text { 2. initially -very } \\
\text { clear }\end{array}$ & $\begin{array}{l}\text { 2. frustration and } \\
\text { confusion }\end{array}$ & multiple interests \\
\hline $\begin{array}{l}\text { 3. freedom from } \\
\text { political pressure on } \\
\text { technical judgment } \\
\text { and procedural } \\
\text { openness } \\
\text { Accountability }\end{array}$ & $\begin{array}{l}\text { 3. initially - very } \\
\text { clear }\end{array}$ & $\begin{array}{l}\text { 3. frustration and } \\
\text { confusion }\end{array}$ & \\
\hline $\begin{array}{l}\text { 2. to be responsive } \\
\text { to the long range } \\
\text { public interest }\end{array}$ & & & $\begin{array}{l}\text { shift in obligation: } \\
\text { first to the elected } \\
\text { officials directly; } \\
\text { then to the larger } \\
\text { "public interest" }\end{array}$ \\
\hline \multicolumn{4}{|l|}{$\begin{array}{c}\text { Serving the Public } \\
\text { Interest }\end{array}$} \\
\hline $\begin{array}{l}\text { 1. concern of long } \\
\text { range impacts } \\
\text { 2. equity in location } \\
\text { of development } \\
\text { project } \\
\text { 3. housing, services, } \\
\text { transportation, land } \\
\text { use, environment }\end{array}$ & & & $\begin{array}{l}\text { to make the } \\
\text { planning process } \\
\text { open to broad range } \\
\text { of interests; to } \\
\text { provide more } \\
\text { equitable } \\
\text { distribution of } \\
\text { information }\end{array}$ \\
\hline
\end{tabular}

Source: Howe (1994) adapted

Notes: Further analysis of each item follows the table format. 


\section{(a) How easily did writer/planner identify what action to take}

1. Not clearly defined: the elected officials did not respond to any information that was generated from planning office

2. Very clear: writer/planner discussed issues with vice-chair of Planning Board, who supported public participation because the planning office and the Planning Board's past policy was open and participatory

3. Very clear: local residents frequently contacted writer/planner's office for information about the proposed gambling casino development

\section{Images Of Role}

\section{(b) Ideal Role versus Actual Role}

The comments below describe the role of writer/planner and how it changed as the nature of the controversial situation changed.

1. As it became evident that council was not responding to writer/planner's request for guidance on responding to public inquiries, writer/planner reassessed the situation and determined the participatory process would be altered or compromised by elected officials who felt public involvement was problematic

2. writer/planner was unable to facilitate open discussion on gaming at the direct order of the elected and appointed officials

3. static nature of Planning Board was unshakable 
With all three scenarios, writer/planner initially saw her role as facilitating the planning process in a manner which had been cultivated through graduate school education, and reinforced by the previous five months of experience in the planning office.

\section{Political Pressure}

Elected and appointed decision makers distanced themselves from the planning office and put pressure on writer/planner not to participate in public discussions concerning the gambling proposal. They ordered her to focus attention on the other "hot topic": the permit for expansion of locally owned gravel and mining operation. Writer/planner was confused and frustrated about how to proceed, as well as angry.

Relating these findings to theories put forth by scholars such as Howe (1994), writer/planner's position as participant observer shows that some aspects of the planning "scenarios" were more clearly defined than others. For example, the first objective--of providing independent professional advice to the Town Council and Planning Board-was clear and writer/planner had no trouble identifying with role as technical advisor. Yet, when the elected officials did not wish to include the public in the decision making process, writer/planner was troubled about what to do.

Similar to the experience in the case example, Howe (1994) describes the situation this way: It is largely the emphasis on the relationship between espoused theory and actual performance, between what planners wanted to do and what they could do. The Town 
Council justified their position by claiming that the "urgency" of the situation did not allow for public input, and that the public disruption from the first meeting made them, (the council and the solicitor) decide limiting the public involvement was in the best interest of providing for the welfare of the town.

However, writer/planner's research and discussions with other professional colleagues clearly discounted this argument. Throughout the state, town planners and officials were conducting public meetings relative to the issues of host communities and gambling casino proposals. In addition, colleagues related suggestions for facilitating public forums, with clearly defined objectives, that would allow for more orderly public discussions.

\section{Value Commitments}

Writer/planner concurs with Howell Baum (1988), who writes both personal role orientations and the politically and bureaucratically complex nature of planning make it difficult for planners to see results from their work--to make what they wanted to do match what they could do.

Values held by writer/planner as experienced in the case example include:

1. values the commitment to planning for the future and notions of the long range nature and the impacts for the "consumers" of the proposed plan; and therefore, values participatory process in the decision making process; values the notion of identifying who has the power and control of which resources (such as information) 
2. values the notion of equity and identifying the potential gains and losses to whom; planning is essentially about providing choices and a key factor in making informed choices is an open fair representation of information; values the notion of identifying whose interests are served by proposed plans;

3. values the relationship between elected and appointed representatives and their constituents; values the obligation to openly discuss plans that affect the residents and communities they serve 


\section{CHAPTER FIVE: CONCLUSIONS}

The moral imagination of students needs to be stimulated. Ethical judgments are involved. sometimes explicitly but more often implicitly, in many planning activities.

Part of the challenge to those teaching ethics in planning schools is to help charge up the ethical batteries of students so that they see more clearly the pervasive ethical dimensions involved in planning work (Kaufman, 1993). 
In the final analysis, the outcome of the events in the case example revealed local constituents resolved the controversial issue -- despite attempts by elected decision makers to close the decision making process:

"Rhode Islanders proclaimed a resounding no to casino gambling anywhere in the state. The West Greenwich Proposal No. 16, on the state ballot, was rejected by $54 \%$ of state's voters, and $64 \%$ in West Greenwich" (Providence Journal Bulletin, November 9, 1994).

\section{Influences on Planners Behavior}

As shown in the case example, writer/planner intervened in a perceived controversial public policy situation which resulted in professional and ethical concerns. What influences had an impact on the writer/planner's role, and what key determinants served as stronger than others? Why did writer/planner act as she did? According to Elizabeth Howe (1994), the explanation must deal with factors that influenced writer/planner at several different levels. In one sense, writer/planner acted as she did because of the professional and ethical values explored in Chapter Four. The actions in the case example were also shaped by more immediate influences which included the political system of the town, as well as the writer/planner's work environment.

\section{Learning On The Job}

Ultimately, the role of writer/planner in this case example also required a certain minimum level of idealism and faith that ethical action was possible, expected, and not 
hopelessly naive. As experienced in the case example, writer/planner agrees with Howe (1994) who writes, that some planners chose roles deliberately; others evolve into them. The process of choice and evolution through experience is the result of the interaction between the planner's ethical values and personalities, and the nature of their political and social environment.

\section{Dependent Variables And The Role of Planners}

If planners act from the base of ethical principles, committed to an open and fair process, then the outcome of the process should be more responsive and fair to those served. Different variables make up different people/planners. What kind of variables seem to explain the difference in professional choices among planners? Probably the most central variable is their role (Thomas, 1991). This project examined the various factors that motivated writer/planner to behave in the manner as experienced in the case example. The focus of this study is primarily on what might be thought of as "dependent variables", that is, the way writer/planner defined ethics, the ethical dilemmas she faced on the job, and how they had been dealt with. The various "independent variables" include the role writer/planner played; the ideas writer/planner had about the public interest; and the organizational factors influencing writer/planner's behavior. The table below was utilized by Howe (1994), and is adapted here to facilitate the objectives of this study. 
Table 6. Variables in the Study

\begin{abstract}
Independent Variables Personal Background

- female; degree candidate for Master in Community Planning; age 35 ; born and lived twenty years in Denver, Colorado; childhood home was in an urban neighborhood; raised in the Christian religion; both parents were college educated-- father, a career professional and mother a homemaker
\end{abstract}

\section{Political}

- liberal $/$ moderate

Values/Substantive Values

- value the basic tenets of human dignity and the right to decent opportunities for all

- value the preservation of the natural environment wherever possible,

- value the independent analysis of data to allow for choice whenever possible

\section{Characteristics of Work Environment}

- local municipality, large rural suburb with low population density

- Agency: sole employee -town planner

\section{Professional Influences \\ Ideal versus \\ Actual Role}

- proactive, administrator of planning related obligations;

- accountable to town council and planning board

Attitude about Citizen Participation

- committed to participatory process and public involvement

- role is to facilitate public and officials as decision makers

\section{Ideas of Public Interest}

Role of Public - Role of Decision Maker

- committed to the role of the planner as facilitator of the process in open, fair process to multiple interests

\section{Dependent Variable \\ Approach to Ethics \\ Scope/Breadth}

(see previous tables and comments)

\section{Substance of Ethics: \\ issues raised principles used}

- technical data reporting/obligation to public as ultimate client

- information dissemination/open, fair process

- agenda item and political pressure on professional judgment/obligation of board to discuss proposals that affect the lives of the constituents

\section{Actions}

(see previous tables and comments)

Nature of Issues

(degree of difficulty in making choice)

- some decisions to act were more difficult than others

- determine whose interest is served

- long term consideration of impacts

Action Taken

\section{Choice of Strategy}

- data collection to superiors, propose public participation, introduce agenda item

Outcome

- no action taken by elected officials

Justification

- legally required

- ethical obligations

- professional principles and personal commitments

Source: Howe (1994) adapted 


\section{Outcomes}

Initially writer/planner experienced high quality job satisfaction because the personal values and professional commitments (to the planning process), she held were in agreement with elected and appointed officials. When the casino gambling proposal was introduced, the former process for analyzing public policy was immediately altered. As experienced in the case example, arguments put forth by other writers (Howe, 1994) are supported by the evidence. For example, while writer/planner experienced little difficulty articulating perfectly acceptable ethical principles which she wished to live by, those same principles were difficult to put into practice. Writer/planner felt the controversial nature of the substantive issue (casino compact), should not change the planning process.

\section{Recommendations: Education as a Force for Change}

While codes of professional conduct may tend to operate as support for ethical positions rather than as a shaping force, professional education would be a way in which the ethical values of new planners could be shaped. Many basic ethical values seem to be set in childhood, and planning schools can only assume that people come with them, but the application of those principles to planning practice is something that planning school can clarify. Values about the public interest and responsibility to officials might be more clearly shaped, particularly for students who had not given these issues much thought. 


\section{Codes For Shaping Action}

Overall, education and professional support may well have less influence on ethical values than other factors, such as childhood upbringing or the constraints inherent in a local culture of planning, but these are the levers that are available to an organized profession for trying to deliberately support and shape ethical action (Howe, 1994).

\section{Exchange of Ideas}

Further research should be done with professional planners, and in the face of change, should explore the practical problems they face. Accounts by practitioners of how they approach their work are invaluable for fellow practitioners, academics and students of planning who wish to contribute to the discussion of effectively linking theory and practice. There is a positive future for planning if planners recognize openly that planning is a political activity, make their values explicit, and apply them consistently (Crawley in Thomas. 1991). 
APPENDIX A 


\section{ORGANIZATION CHART}

\section{ELECTORATE}

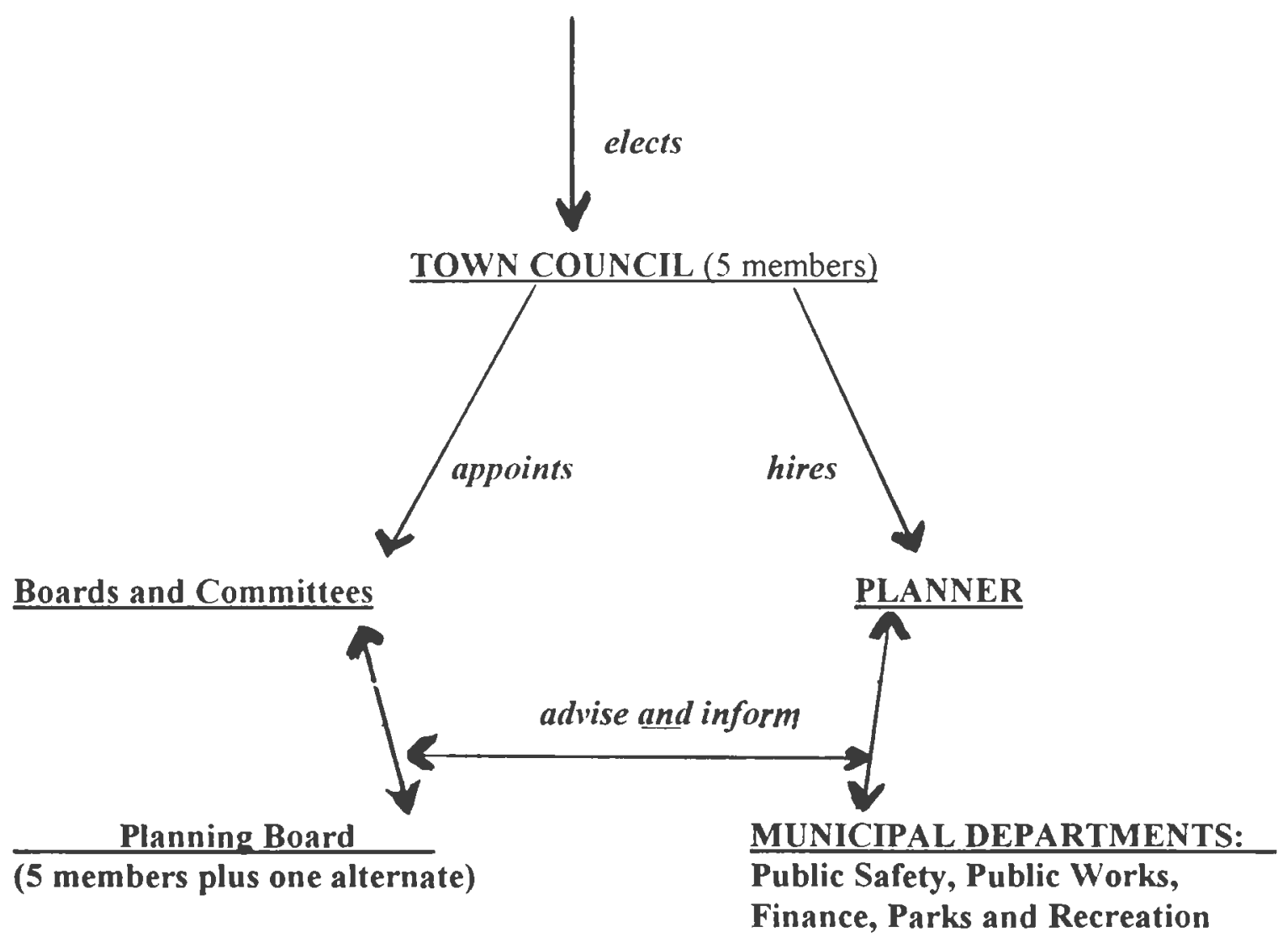

Figure 4: $\quad$ Organizational Chart (Appendix A) 


\section{HIGHLIGHT FROM THE COMPACT BETWEEN SUNDLUN AND}

\section{NARRAGANSETTS}

-provided that the Narragansett Indian tribe operates the only gaming facility in the state and provided that is located in West Greenwich (as defined in compact, p.2-3) the tribe will contribute $16.5 \%$ of its gross revenues to the state. If however, any other casino begins operation in the state, this percentage will drop to $2 \%$. The state will still be required to maintain all other provisions of the compact (Section 14(b)(i), (ii), (iii): 66-67)

- this is a minimum ten year commitment with the tribe (Section 15(a): 68)

- if the compact is approved and the legislature tries to adopt laws to regulate the casino in any way that will cause a loss of profit, any negative impact on the casino's profits will be accounted for and this amount of money will be deducted from the money that is given to the state by the tribe (Section 15(h): 71-72)

- if there is any change in the federal tax laws regarding Indian gaming, the tribe will sit down and negotiate the amount of money given to the state to take into account the additional taxes that the tribe must pay. Worst case scenario is state would receive no revenue from gaming casino (Section 19: 74)

- the state will pay for the costs of doing background and criminal record checks for those people applying for jobs at the casino who need to be licensed as gaming employee (Section 5(c): 26-27)

- if the Jai Alai Fronton in Newport closes, the tribe shall be permitted to build their own facility (Section 3(b)(v): 15)

-the tribe is entitled to run its own lottery games including telephone betting on them (Section 3(b)(iii): 15)

- the tribal law enforcement agency shall have the authority to detain any non-Indian for violations of state law and shall promptly transfer such person to the nearest state police officer or facility for processing (Section 4(d) (iii): 21

- the state police shall have no authority to enforce Narragansett tribal laws unless called upon for assistance by the tribe (Section 4(f) (iv): 24

- at the discretion of the tribal government, the Indian violator may be turned over to the state police for processing under state law (Section 4(e)(iii): 22

- if the tribe wants to run special forms of betting games, all they are required to do is to apply to the state gaming agency for approval; if they do not hear from the state agency within twenty business days, they are granted an automatic approval (Section $8(d): 47$

- while the records of the gaming operation are open to state review, these records are not open to public disclosure (Section 12(b): 58

- the tribe has been given pre-approval to serve and distribute liquor essentially in any building on the site of their gaming facility be it the gaming floor or not (Section 13(b): 64

- the state does not have 24-hour liquor laws, but if this compact is passed, the state is obligated to try and pass a law allowing it for the tribe's gaming facility (Section 13(b): 64 


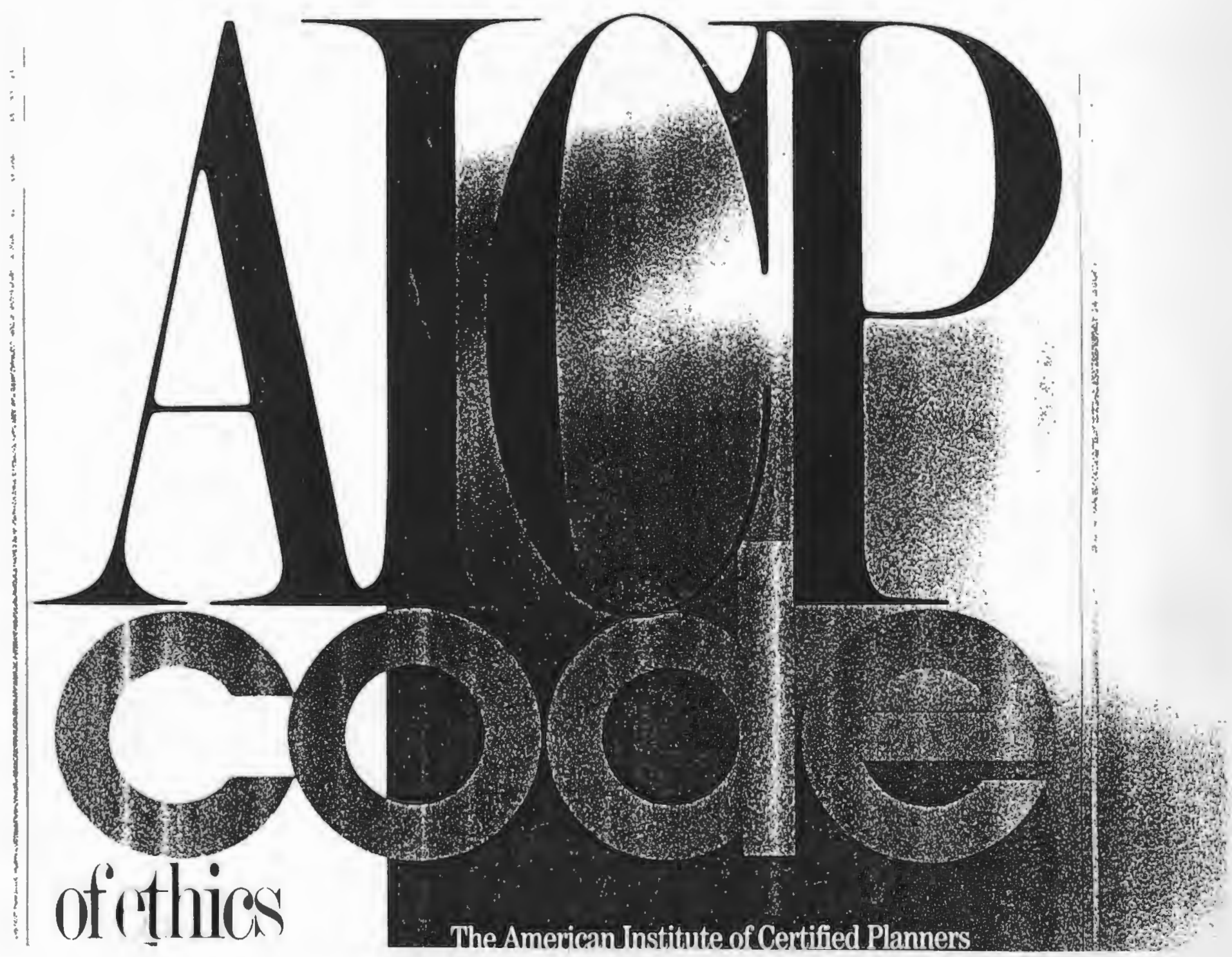




\section{AVCl P Code of Ethics and Professional Conduct}

(Adopted October 26, 1990)

This Code is a guide to the ethical conduct required of members of the American Institule of Cenified Planners. The Code also aims at informing the public of the principles to which professional planners are committed. Systematic discussion of the application of these pnnciples. among planners and with the public. is itself essential behavior to bring the Code into daily use.

The Code's standards of behavior provide a basıs for adjudicaung any charge that a member has acted unethically. However. the Code also provides more than the minımum threshold of enforceable acceptability. It sets aspirational standards that requin conscious striving to atcain.

The prnciples of the Code derive both from the general values of sosiety arid fro.n the planning profession's special responsibility to serve the public interest. As the basic values of society are often in competi. tion with each other. so also do the principles of this Code sometimes compete. For example. the need to provide full public information may compete with the need to respect confidences. Plans and programs often result from a balancing among divergent interests. An ethical judgment often also requires a conscientious balancing, based on the facts and context of a particular situation and on the precepts of the entire Code. Formal procedures for filing of complaints, investigation and resolution of alleged violations and the issuance of advisory rulings are part of the Code.

\section{The Planser's Reapondibility to the Publie}

A. A planner's primary obligation is to serve the public interest. While the definition of the public interest is formulated through continuous debate, a planner owes allegiance to a conscientiously attuined concept of the public interest, which requires these special obligntions:

1) A planner must have speciul concern for the long range epnsequences of present actions

2) A planner must pay special attention to the interrelatedness of decisions.

3) A planner must strive to provide full. clear and accurate information on planning issues to ciuzens and govemmental decision-makers.

4) A planner must strive to give citizens the opportunity to have a meaninfol impact on the development of plans and programs. Participation should be brond enough to include people who lack formal organization or influence.

5) A planner must strive to expand choice and opporunity for all persons. recognizing a special responsibility to plan for the needs of disadvantaged groups and persons, and must urge the alteration of policies, institutions and decisions which oppose such needs.

6) A planner must strive to protect the integrity of the natural environment.

7) A pianner must strive for excellence of environmental design and endeavor to conserve the heritage of the built envitonment.

\section{The Planoer's Responsibillty to Clieats and Employer}

B. A planner owes dilizent, creative, independent and competent performance of work in pursuit of the client's or employer's interest. Such performance should be consistent with the planner's faithful service to the pub!ic in'srest.

1) A planner must exercise independent professional judement on behalf of clients and employers.

2) A planner must accept the decisions of a client or employer concerming the objectives and nature of the professional services to be pefformed unless the course of action to be pursued involves conduct which is illegl or inconsistent with the planner's primary obligation to the public interest.

3) A planner must not, without the consent of the client or employer, and only atter full disclosure, accept or continue to perform wort if there is an actual, apparent, or reasonably foreseeable conflict between the interests of the client or employer and the persond or financial interest of the planner or of another past or present client or employer of the planner.

4) A planner must not solicit prospective clients or employment throuch use of false or mislesdins claims, haressment or doress.

5) A planner must not sell or offer 10 sell services ify simtins or inf!ying an ability to influence decisions by improper means.

6) A planner must not use the power of eny ofice to seet or obtuin a special dvantage that is not in the public interest nor any special edvantage that is not a matter of public knowledge.

7) A planner must not accept or continue to perform wort beyond the planner's professional compelence or sccept wort which cannot be performed with the promptness required by the prospective client or employer, or which is required by the circurnstances of the assienment.

8) A planner must not reveal information gained in a professional relationship which the client or employer has requested be held inviolate. Exceptions to this require. ment of non-disclosure may be made only when (a) required by process of law, or (b) required to prevent a cleas violation of law, or (c) required to prevent a substantial injury to the public. Disclosure pursuant to (b) and (c) must not be made until afler the planner has verified the faces and issues involved and, when practicable, has exhusted efforts to obtain reconsideration of the matter and has sought separate opinions on the issue from other qualified profes sionals employed by the client or employer

\section{The Phaser's Respoasibility to the Profession and to Collengues}

C. A planner should contribute to the development of the profession by improv. ing knowledge and techniques, making work relevant $w$ solutions of community problems, and increasing public understanding of plannin.3 activicies. A planner should treat faitly the professional views of qualified colleagues and members of other professions.

1) A pianner must protect and enhance the integrity of the profession and must be responsible in criticism of the profession.

2) A planner must accurately represent the qualifications, views and findings of colleagues.

3) A planeer tho reviewe the wotk of other profeselomal mint do so 10 - falr, conelderate, profeasional and equitable anner.

4) A planner must share the results of experience and research which contribute to the body of planning knowledge.

5) A planner must examine the applica. bility of planning theories, methods and standards wo the facts and analysis of each particular situation and must not accept the applicability of a customary solution with out first establishing its appropriateness to the situation.

6) A planner must contribute time and information to the professional develop. ment of students, interns. beginning professionals and other colleagues.

7) A planner must strive to increase the opportunities for women and members of recognized minorities to become professional planners.

8) A planer shall not count an act of sexual herasemant.

\section{The Plander's Self-Responsibility}

D. A planner should strive for high standards of professional integrity, profi. ciency and knowledge.

1) A planner must not commit a delib erately wrongful act which reflects adversely on the planner's professional fitness.

2) A planner must respect the rights of others and. in particular. must not improperty discriminate agaınst persons.

Continued 
American

Institute of

Certified

Planners

An Institute of the

American Planning Association

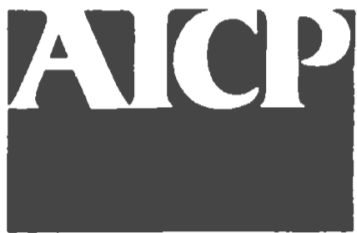

Ethics Advisories. The AICP Code of Ethics and Professional Conduct provides for advice by the executive director on specific problems and yues. tions conceming ethical behavior by members The AICP Ethics Committee asked that such advice be codified as advisory rulings specificd by the code.

\section{Advisony Ruling No. 1: Sexual Harassment}

Sexual harassment is unethical under the AICP Code of Ethics and Professional Conduct. Sexual harassment is also subject to penalty under law. The U.S. Equal Employment Opportunity Commission defines sexual harassment as: "Unwel. come sexual advances, requests for sexual favors, and other verbal or physica! conduce of a scxual nature constitute sexual harassment when: 11 Submission to such conduct is made either explicitly or implicitly a term or condition of an individual's employment; 21 Submission to or rejection of such conduct by an individual is used as the basis for employment decisions affecting such individual; or 3) Such conduct has the purpose or effect of unreasonably interfering with an individual's work performance or creating an intimidating, hostile, or offensive working envi. ronment."

Two of the general principles in the Code are applicable to specific instances of harassment: Principle D (1) of the Code says that a planner must not commit a deliberately wrongul act which reflects adversely on the planner's profes. sional fitness; and Principle D (2) of the Code says that a planner must respect the rights of others and, in particular, must not improperly discrim. inate against persons. Unlawful scxual harassment as defined by the EEOC is a deliberately wrongful act.

Respecting the rights of others, under the Code, requires a standard of behavior higher than that defined as coercive or intimidating by EEOC. Conduct that may not have illegal effect may nevertheless be harassment. Joking or ban. tering about sexual subjects, comments sug. gesting sexual attractiveness, and comments disparaging women or men or their abilities generally may constitute petty harassment. If any such behavior is found offensive, offended persons should so say. The offensive behavior becomes harassment if continued after the offender is notified.

Negligence or omission on the part of an employer who is dismissive of a complaint of sexual harassment, and encourages the complainant to be tolerant of the offense is itself a form of harassment So is a deliberately false accusation of sexual harassment.

Harassment is decidedly distinct from behavior occasioned when a genuinely mutual affection springs up betwecn co-workers. (May 19881

Advisory Ruling No. 2: Conflicts of Interest When a Public Planner has a Stake in Private Development

The Code of Ethics and Professional Conduct addresses conflicts of interest in Principle B (3): "A planner must not, without the consent of the client or employer, and only after full disclosure, accept or contınue to perform work if there is an actual, apparent, or reasonably foresceable conflict between the interests of the client or employer and the personal or financial interest of the planner or of another past or present client or employer of the planner."

Conflicts of interest are rcasonably foresecable when a planner attempts to serve a real estate development clicnt while also serving a public agency that may have a role in reviewing or approving projects of that client

Inquines from planners who contemplate com bining activity in the real estate business with public planning work have fallen into a pattem as have the responses

Real estate is a popular investment, and plan ners, knowing a lot about it, are attracted to it.

"I have an opportunuty to invest in a small development, but the proposal will come before my agency for approval. What do you advise?" Don't do it. There are other investment opportunities

"What if it's put in my wife's name:" Your wife's financial interest is your financial interest and yours is hers.

"But, when it comes before us, I will exclude myself from the decision, and only other staff members will recommend on the proposal. I won't take part at all." Your colleagues work with you, know that your interests are involved, and can't eliminate the influence of your relationship with them, even if unexpressed.

"My influence really can be a positive one on the developer. I know what would be good for the public and can work for a good design." That's what your agency is there for, and that's why it has the power to review and approve.

"But what if I disclose everything to the director, and he gives his consent ...?" He shouldn't. I cerainly would advise him not to.
"I will work for a broker in a neighboring purisdiction across the state line. He docsn't have a license in that state." No, but some of his colleagues do. And some of the decisions affeceing the broker's business are regional decisions involving both jurisdictions.

A code of ethics should not be a what-can-I. get-away-with code. It should not be torured into loopholes and technicalities that would al. low a person to be formally conect whilc ethi. cally wrong. The AICP Code looks for "more than the minimum threshold of enforceable acceptability. It sets aspirational standards that require conscious striving to attain."

Developers can henefit from professional plan. ning services and are just as entitled to fully conscientious advocacy of their interests as a public planning agency. A conflict of interest is inherent, however, in any assumption of both roles simultaneously.

There may also be a conflict when the roles overlap. A planner may move from employmene by a public agency to employment by a private client. A conflict arises as soon as discussion is initiated for such a move. The public employer must, therefore, be notified promptly that such discussion has taken place whether or not it matures in a change of employment. This is decidedly earher notice than is normal for a job change and it is notice of a change that may not take place. It is necessan; however, to guard against the substantial conflicts that would occur if a planner is in a position to influence the resolution of certain issues in public employ that will later affect the interests of a new, private employer.

Private planners and consultants who undertake work for a public agency, or change employment from private to public, must disclose any conflicts or potential conflicts to the public agency employer. (May 1988)

\section{Advisory Ruling No. 3: Outside Employment or Moonlighting}

A planner's responsibility to an employer places significant restraints on accepting work for em. ployers outside of the full-time commitments to the primary employer. A full-time member of a planning agency staff owes loyalty, energy and powers of mind primarily to its service.

The Principles in the Code that concem conflict of interest $[B|3|]$ and using an office to seek special advantage $[B|6|]$ must especially be applied. 
A planning staff member must take no $\mathrm{cm}$. ployment outside of official duties unless such employment creates no conflict with those du ties etther in the interests to be served or in competition for time and energy. If the planner decides that there will be no such conflicts, then outside employment must, in addituon, receive the explicit approval of the employer

No outside employment must be underaken if its performance will reduce the quality or dispatch with which the staff member executes primary responsibilities. The number of hours and the scheduled times devoted to outside $\mathrm{cm}$. ployment must not interrupt or interfere with the time that the primary responsibiluties $\mathrm{de}$. mand.

Outside employment must never deal with any matter that may require an action or recom mendation by the primary employing agency Neither must employment be taken with any person or organization that does business with any agency of the primary employer

Public property must not be used for any private purpose including work that is ferturmed for other employers

Principle B (7) says that "A planner must not accept ... work beyond the planner's professional competence or accept work which cannot be performed with the promptness required. Since the schedules, deadlines, pnonties and un. anticipated time demands of the primary em. ployer must always take precedence, the volume of outside work must necessarily be small and an outside employer must be informed that prompt execution will not necessarily be satisfied.

Both the planner requesting, and the authonty giving, approval for outside employment should consider the main justification for approval is a demand for whatever special professional know!edge and experience tbe planner has that is not otherwise readily available. Service as a teacher or instructor is outside employment that is most justifiable and an unspecialized, general consult. ing practice least justifiable. (May 1988)

\section{Advisory Ruling No. 4: Honesty \\ in the Use of Information}

As professional givers of advice-advice that may affect the well-being of communities and individ. uals for many years - we have a special obligation to cherish honesty in the information that supports our advice.

Yet, many daily pressures do battle against honesty. We are pressed to be effective advocates for a community, a private client, an elected administration or a cause. A political agenda is often formed before dispassionate study; those who have campaigned for it then look with passion for studies to support it. Decision-makers may demand a greater dégree of certainty, or impose more rigorous criteria for decision, than the capabihty of analysis or sufficiency of data can satusfy:

The Code of Ethics and Professional Conduct is filled with prescriptions for honesty

A-3| "provide full, clear and accurate information on plannıng issues to citizens and govemmental decision-makers."

B-3| "only after full disclosure" (on conflicts of interest)."

B-4) "must not ... through use of false or misleading claıms."

B-7) "must not accept ... work beyond the planner's professional competence."

C.1) "must protect and enhance the integrity of the profession."

C-2! "must accurately represent the qualifications, vews and findings of colleagues."
D.4) "must accurately represent |one's own professional qualıfications, education and affilta. tions."

In some situations, planncrs must not provide full information. Planners frequently have the role of negotiators whose effectiveness depends on not disclosing final positions that are accept able. And, as the Code pornts out, "the need to provide full public information may competc with the need to respect confidences." Informa. tion that is disclosed in such circumstances must however, be honest and accurate.

It is par of professional conduct to communicate our ethical standards to clients, employers and the public. Communicating them early, be fore they need to be applsed to a specific controversy, may ease pressures to abuse them.

There should be no need to explain what the code requires as full, clear and accurate information. Half-truths, deceptions and undocumented assertions don't pass. A half-truth is a wholc lic Don't cook the numbers.

There is also a positive duty on behalf of ethical treatment of infomiation. In reporing the results of studies, planners must follow the schol. ar's rulc of making it possible for others to follow in our footsteps and check our work. Document the sources of data. Repor the statistical proce. dures used, what was done to bring the raw data into the form that is reported. What assumptions were made at different stages in the study?

Public decision-makers must often leap beyond the cautions and reservations of a careful study to achieve political solutions. Planners must take pains that our studies and recommen dations are not wrongly interpreted, and that a clear distinction is made between factual findings and policy decisions. (March 1991 ) 


\section{American Planning Association Statement of Ethical Principles for Planning}

The Board of Directors of the American Planning AssociPlanning at its meeting in New York City on April 26, 1987.

The statement is aimed at both practicing planners and public planning officials (planning commissioners, board of zoning appeals members, architectural review commission members, etc.) and establishes guidelines ation adopted this Statement of Ethical Principles for

for ethical conduct. It is intended to complement the AICP Code of Ethics and Professional Conduct, which applies to AICP members only.

Members of the AICP ethics committee included: Stuart Meck, chair; Carol D. Barrett, Richard Bickel, Jerome L. Kaufman, Martin Wachs, Stephen A. Kaufman (ex officio), J.D. Wingfield, Jr. (ex officio).

\section{Ethical Princtiples for Planning}

been prepared by the American Planning Association, an organization whose purpose is to advance the art and science of planning-physical, economic, and social-at the local, regional, state, and national levels.

. To carry out this purpose arid objective, the APA has adopted this Statement to guide APA members, public planning officials, and others. : :

$\therefore$ is:

As defined in this Statement, a planner is one who, as p principal means ớ liveliho od, is engaged in the activities of planning, which is the application of research, knowledge, and foresight to action in the publicinterest

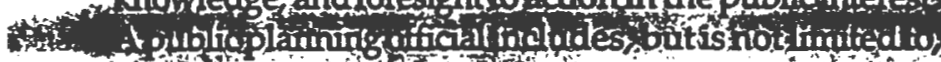

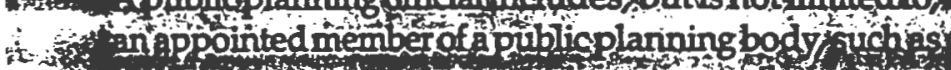

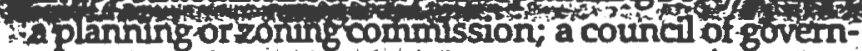
ments; boaird of zoning appeals or zoning adjustment; in architectural design or historic review commission:

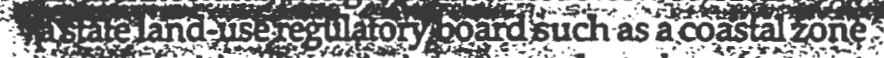
or power siting commission; or an elected government official who is engaged in planning, zoning, community. development, or capital buadgeting and who makes pub; - lic planning decisions, fiss in

This Statement establishes guidelines for ethical conduct to assure that those individuals whose decisions and actions have long-range consequences for later zenerations may;merit the respect and confidence of other officials, public employees, professional planners, and the public:By distributing this Statement, APA seeks to promote ethical principles in planning and public discussion of ethical practice. APA members who are also members of its professional affiliate, the American Institute of Certified Planners (AICP), are subject to a separate AICP Code of Ethics and Professional Conduct, which provides for an enforcement procedure? This Statement is intended to complement the I' " code. APÁ encorirages the adoption of theprifictes in this Statement by legislatures through or ininces or fatutes, by public planning bodies through incorporation into bylaws, and by employers of planners, who may include them in personnel manuals and other employment policy documents.
In this Statement, the terms "planner" and "public planning official" also refer to a member of the American Planning Association. Where the ethical principles refer to a "planner," they apply to planners working in the public and private sectors, unless otherwise specified. The responsibility of private sector planners to represent their clients must be balanced against the need to promote the principles in this Statement. An ethical approach to planning transcends the boundaries between the public gnd privatesectors.

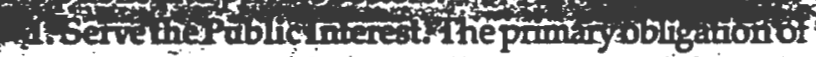
plannersañ public planing officialsis tolenthth ific interest.t. 2.'Support Citizen Participation in Planning. Because the definition of the public interest is continuously modi-. thed, the planner and public planning officil mutst recogthize the tight of citizens to influence planning decisions that affect their well being. They should adyocate f fo- $^{2}$ Fuim for meaningful citizen participation and expression in the planning process and assist in the clarification of community goals, objectives; and policies in planmaking. Recognize the Comprehensive and Long-range Nature of Planning Decisions. The planner and:public planning official must recognize and have special concern for the comprehensive and long-range nature of planning decisions. The planner and official must balance and integrate physical (including historical, cultural, and natural), economic, and social characteristics of the community or area affected by those decisions. The plannier and official must continuousty gather and consider in trevant facts, ilternatives, and means of acoinplis $;$ hem. The planner and official should exb ticity ev ifiate all consequences beforemaking a recom-

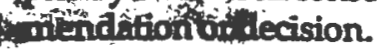

4. Expand Choice and Opportunity for All Persons. The planner and public planning official must strive to expand choice and opportunity for all persons, recognize a special responsibility to plan for the needs of disadvan- 
taged people, and unge changing policies, institutions, and decisions that restrict their choices and opportunities.

5. Facilitate Coordination Through the Planning Process. The planner and public planning official must facilitate coordination. The planning process should enable all those concemed with an issue to learn what other participants are doing, thus permitting coordination of activities and efforts and accommodation of interests. The planner and official must ensure that individuals and public and private agencies possibly affected by a prospective planning decision receive adequate information far enough in advance of the decision.

6. Avoid Conflict of Interest. To avoid conflict of interest and even the appearance of impropriety, the public planning official who may receive some private benefit from a public planning decision must not participate in that decision. The private benefit may be direct or indirect, create a material personal gain, or provide an advantage to relations, friends, groups, or associations that hold a significant share of the official's loyalty. An official with a conflict of interest must make that interest public, abstain from voting on the matter, not participate in any deliberations on the matter, and leave any chamber in which such deliberations are to take place. The official must not discuss the matter privately with any other official voting on the matter. A private sector planner who has previously worked for a public planning body on a plan or project should not appear before that body representing a private client in connection with proposals affecting that plan or project for one year after the planner's last date of employment with the planning body.

7. Render Thorough and Diligent Planning Service. The planner and public planning official must render thorough and diligent planning service. Should the planner or official believe s/he can no longer render such service in a thorough and diligent manner, s/he should resign from the position. If the official has not sufficiently reviewed relevant facts and advice affecting a public planning decision, the official must not participate in that decision.

8. Not Seek or Offer Favors. The publicsector planner and public planning official must seek no favor. The planner and official must not direct ty erindirectly solicit anty gift or accept or receive any gift (whether in money, services, loans, travel, entertainment, hospitality, promises, or in some other form) under circumstances in which it could be reasonably inferred that the gift was intended or could reasonably be expected to influence them in the performance of their duties or was intended as a reward for any recommendation ordecisinnon their part. The private sector planner must not offer any gifts or favors to influence the recommendation or decision of a public sector planner or public planning official. The private sector planner should oppose such action by a client.

9. Not Disclose or Improperly Use Confidential Information for Financial Gain. The planner and public planning official must not disclose or improperly use confidentiat thformation for financial gain. The planner and official must not disclose to others confidential information acquired in the course of their duties or use it to further a personal interest. Exceptions to this requirement of non-disclosure may be made only when (a) required by process of law, or (b) required to prevent a clear violation of law, or (c) required to prevent substantial injury to the public. Disclosure pursuant to (b) and (c) must not be made until after the planner or official has verified the facts and issues involved, has exhausted efforts to obtain reconsideration of the matter, and has sought separate opinions on the issue from other planners or officials.

10. Ensure Access to Public Planning Reports and Studies on an Equal Basis. The public planning official must ensure that reports and records of the public planning body are open equally to all members of the public. All non-confidential information available to the official must be made available in the same form to the public in a timely manner at reasonable or no cost.

11. Ensure Full Disclosure at Public Hearings. The public planning official must ensure that the presentation of information on behalf of any party to a planning question occurs only at the scheduled public hearing on the question, not in private, unofficially, or with other interested parties absent. The official must make partisan information regarding the question received in the mail or by telephone or other communication part of the public record.

12. Maintain Public Confidence. The public planning official must conduct himself/herself publicly so as to maintain public confidence in the public planning body, the official's unit of government, and the official's performance of the public trust.

13. Respect Professional Codes of Ethics and Conduct. The planner and public planning official must respect the professional codes of ethics and conduct established by the American Institute of Certified Planners (AICP) Commmission and by several professions related to the practice of planning. Professional codes commonly establish standards of professional conduct and include provisions that protect the integrity of professional judgment and describe the professional's responsibility to the public, clients, employers, and colleagues.

\section{Procedures for Advisory Ethics Opinions}

APA will provide advice and information on ethical concerns related to planning. Any person may file a written request with the executive director of APA for an advisory opinion on the propriety of any planning conduct. The request should contain sufficient facts, real or hypothetical, to permit a definitive opinion. The executive director shall refer the matter to an ethics committee appointed by the APA president.

After consultation with the APA ethics committee, the executive director shall then provide a written advisory opinion to the inquiring party. The opinion may be published if endorsed by the committee. Published opinions shall not include actual names and places without the written consent of all persons to be named. 
APPENDIX B 


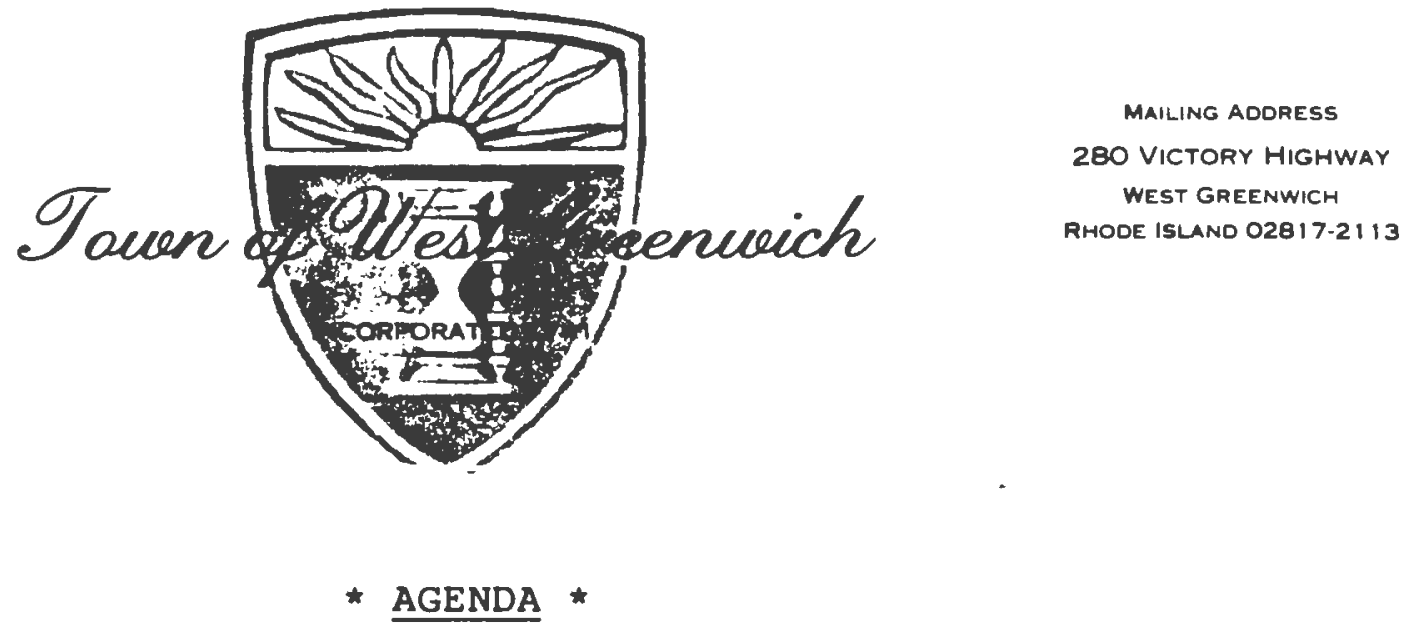

AGENDA :

PLANNING BOARD - REGULAR MEETING

MONDAY 3 OCTOBER 1994

$7: 30$ P.M.

CALL TO ORDER

ACCEPTANCE OF MINUTES OF PREVIOUS MEETING

REVIEW OF APPLICATIONS \& REQUEST FOR ADVISORY OPINIONS

- NONE -

REVIEW OF SUBDIVISIONS

1) Valley Brook Partners (Robert Cioe)

- replat due to engineering survey error

\section{CORRESPONDENCE}

1) Gervasini scheduling request

2) invoices from Maguire Group Inc

NEW BUSINESS

1) discussion of proposed Narragansett Indian Tribe/Gaming International casino

- consideration to planning issues including benefits and constraints; will sovereignty supersede local planning and zoning authority; land use regulations, water and natural resource conservation, etc.

\section{OLD BUSINESS}

\section{ADJOURN}

The Town of West Greenwich will provide interpreters for the hearing impaired at any meeting provided a request is received 3 business days prior to said meeting.

An audio tape copy of the minutes will be provided if requested by a vision impaired person at least 48 hours in advance of the meeting date. 


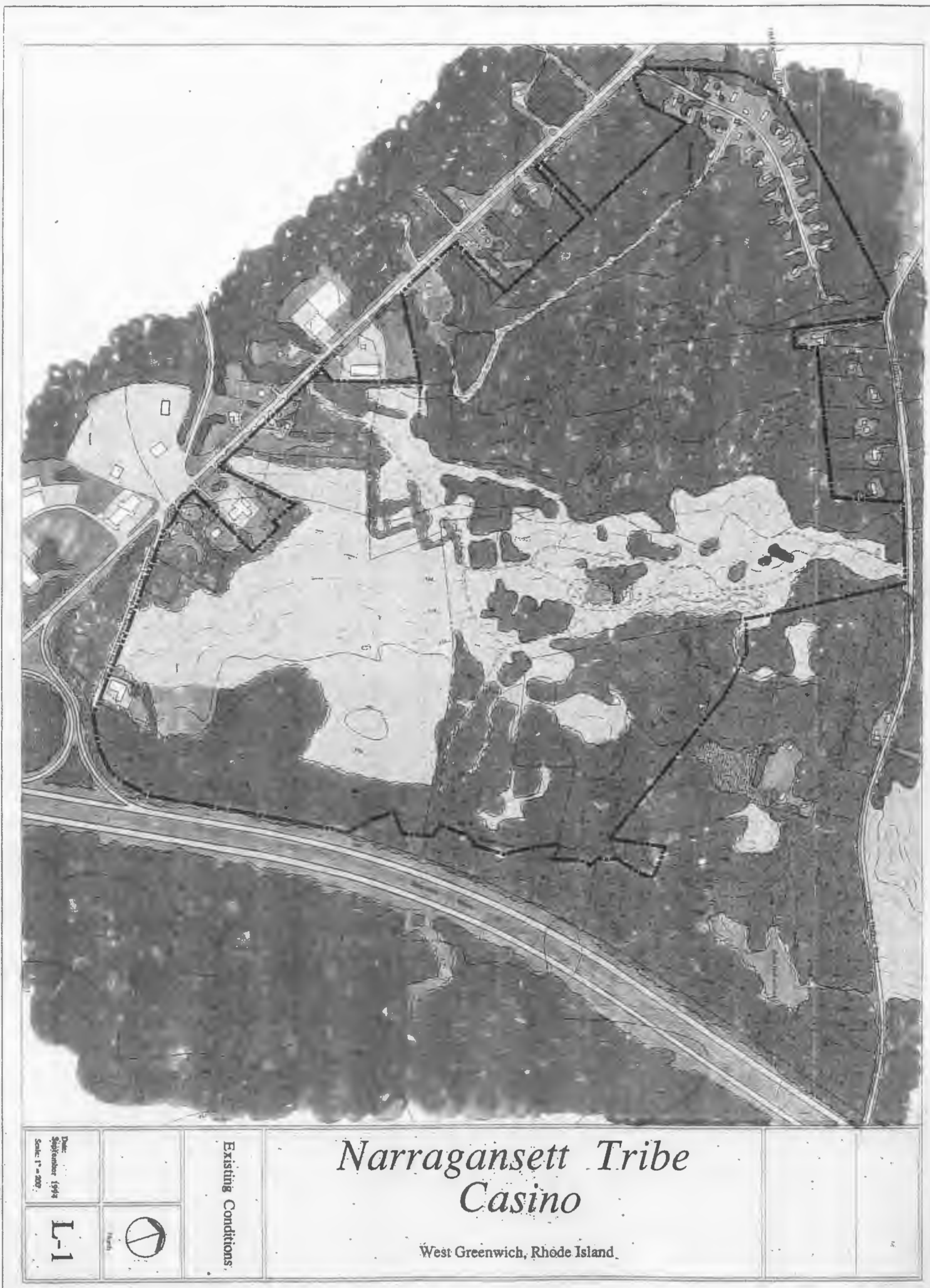




\section{NARRAGANSETT TRIBAL GAMING FACILITY}

1. Print clearly and press firmly with a ball point pen.

2. Answer each question completely and accurately.

3. Read Certification and Release carefully.

4. Please sign where indicated.

Entry Date Seq\#

Personnel Rep.

\section{EMPLOYMENT APPLICATION}

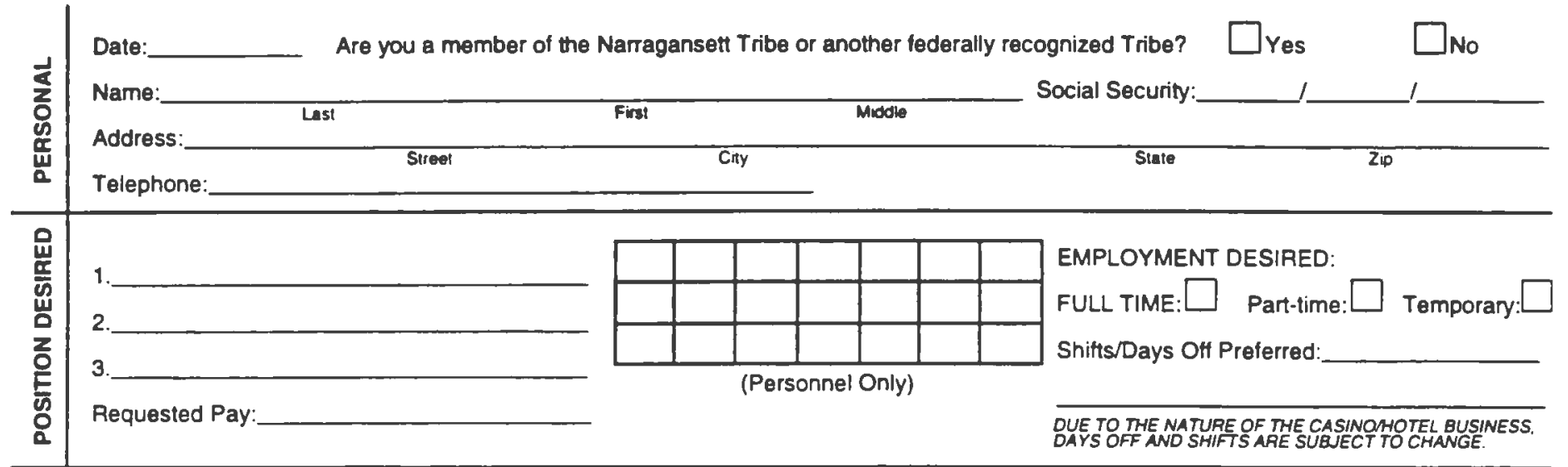

$\bar{\Sigma}$

$\frac{\text { 뜬 }}{\frac{1}{5}}$

Do you have the legal right to work in the United States?

You will be required to present proof of identity and employment eligibility.

Are you 18 years of age or over?

Have you ever been convicted of a crime other than a traffic violation?

If yes, Date:

City:

Disposition:

$\square$ Yes $\square$ No

$\square$ Yes $\square$ No

$\square_{\text {Yes }} \square$ No

\begin{tabular}{|c|c|c|c|c|}
\hline & $\begin{array}{l}\text { If yes, Date: } \\
\text { Disposition: }\end{array}$ & _ City: & & \\
\hline \multirow{5}{*}{ 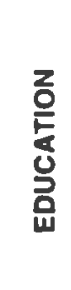 } & & SCHOOL, NAME AND LOCATION & $\begin{array}{l}\text { Highest Grade } \\
\text { Completed }\end{array}$ & $\begin{array}{c}\text { Type of Degree } \\
\text { or Diploma } \\
\end{array}$ \\
\hline & High School & & & \\
\hline & College & & & \\
\hline & Graduate & & & \\
\hline & Other Special Training & & & \\
\hline
\end{tabular}

MILITARY SERVICE: Are you a veteran of the U.S. Amned Forces? Service Branch
Date Enlisted:

\section{FOREIGN LANGUAGE ABILITIES}

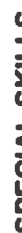

1.

2.

3.
OFFICE SKILLS

Speak Read Write

$\square \quad \square$

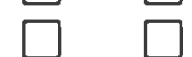

Dictating Machine $\square$

Speed

Speed

Computer $\square$ Type:

Other:
Word Processor $\square$

Final rank: Date Discharge: 


\section{Narragansett Indian Tribal Information Center Constituent Opinion Form}

Name:

Street Address:

Town:

Zip Code:

Telephone:

Date:

Concern: 


\section{RESEARCH BIBLIOGRAPHY}

Andranovich, Gregory D. and Gerry Riposa. 1993. Doing Urban Research, Applied Social Research Methods Series, vol. 33. Newbury Park: Sage

Babbie, Earl. 1992. The Practice of Social Research, 6th ed. Belmont, CA: Wadsworth.

Baum, Howell S. 1988. Why' Do Planners Do What They Do? The Little We Know' And

The Lot We Don't. Paper presented to the Association of Collegiate Schools of Planning Annual Meeting, Buffalo, New York.

Checkoway, Barry. 1994. Paul Danidoff and Adrocacy Planning In Retrospect. Journal of the American Planning Association. 60: 139-143.

Clavel, Pierre. 1994. The Evolution of Adrocacy Planning. Journal of the American Planning Association. 60: 146-148.

Davidoff, Paul; Davidoff, Linda and Neil Gold. 1970. Suburban Action: Advocate Planning For An Open Society. Journal of the American Institute of Planners. 36, 1: 12 21. 
Feld, Marcia M. and Howard H. Foster Jr. 1990. Peer Support In Decision-Making: Is There A Need For A Professional Community? Paper Presented To The Association of Collegiate Schools of Planning Annual Meeting, Austin, Texas.

1989. The Yonkers Case And Its Implications For The Teaching and Practice of Planning. Journal of Planning Education and Research. 8:3, 169-176.

1986. Planners Guilty On Two Counts. The City of Yonkers Case. Journal of the American Planning Association. 52: 387-388.

Forester, John. 1994. Bridging Interests And Community: Adrocacy Planning And the Challenges Of Deliberative Democracy. Journal of the American Planning Association. 60: $153-157$.

1982. Planning In The Face Of Power. Journal of the American Planning Association 48:67-80.

Gans, Herbert J. People, Plans, and Policies. 1991. New York: Columbia University Press.

Hendler, Sue. 1994. Ethics In Plamning: The Views of Students and Practitioners. Journal of Planning Education and Research. 10:2, 99-104. 
Howe, Elizabeth. 1994. Acting On Ethics in City Planning. New Jersey: Published by the Center for Urban Policy Research.

1980. Role Choices of Urban Planners. Journal of the American Planning Association. 46: 398-409.

and Kaufman, Jerome. 1981. The Values of Contemporary American Planners.

Journal of the American Planning Association. 47: 266-278

Jones, Bernie. 1990. Neighborhood Planning: A Guide for Citizens and Planmers.

Washington DC: Planners Press. American Planning Association.

Kaufman, Jerome L. 1993. Reflections On Teaching Three V'ersions Of A Planning Ethics Course. Joumal of Planning Education and Research. 12: 107-115.

1981. Ethics and Planning: Some Insights from the Outside. Journal of the American Planning Association. 47: 196-199.

Klosterman, Richard E. 1990. Community Analysis And Planning Techniques. Savage, Maryland. Rowman and Littlefield Publishers, Inc. 1985. Arguments For And Against Planning. Town Planning Review. 56: 5-20. 
Krumholz, Norman and Pierre Clavel. 1994. Reinventing Cities: Equity Planners Tell Their Stories. Philadelphia: Temple University Press.

1982. A Retrospective View of Equity Planning: Cleveland 1969-1979. Journal of the American Planning Association. 48: 163-174.

Levy, John M. 1994. Contemporary Urban Planning. New Jersey. Prentice-Hall Inc.

Marcuse, Peter. 1976. Professional Ethics And Beyond. Values In Planning. Journal of American Institute of Planners. 42, 3:264-274

Rothman, Jack, John L. Erlich and Joseph G. Geresa 1981. Changing Organizations and Community Programs. California: SAGE Publications

Schein, Edgar H. 1987. The Clinical Perspective in Fieldw'ork. Newbury Park: Sage Publications

Schon, Donald A. 1982. Some Of What A Planner Know's: A Case Study of Knowing In-Action. Journal of the American Planning Association. 48: 351-364.

Smith, Nick J. (Ed.). Varieties of Investigative Evaluation. 1992. San Francisco. JosseyBass Publishers. 
Stewart, David W. and Michael A. Kamins. 1993. Secondary Research: Information Sources and Methods. Newbury Park: Sage Publications

Thomas, Huw and Patsy Healy. 1991. Dilemmas of Planning Practice: Ethics, Legitimacy and the Validation of Knowledge. Vermont: Gower Publishing Company.

Wachs, Martin (Ed.). 1985. Ethics In Planning. New Jersey. Center For Urban Policy Research.

Weiss, Carol H. 1972. Evaluation Research: Methods for Assessing Program Effectiveness. New Jersey. Prentice-Hall.

Yin, Robert K. 1989. Case Study Research: Design and Methods. Newbury Park: Sage Publications

\section{INDIAN GAMING RESEARCH BIBLIOGRAPHY}

Blechman, Andrew D. Casino: A Bane and a Bonanza in Norwich Bulletin, August 14, 1994.

Two Casinos: Key is Service in Norwich Bulletin, July 17, 1994.

and David Rivera. Planners Gridlocked: Traffic Solutions Needed, But Light Rail

Deemed Impractical. July 17, 1994.

Bogert, Carroll. Casino Clout for Native Americans in Newsweek, March 28, 1994. 
Brown, Michael G. Hourly Wage is Only Part of Story in Pequot Times, September 1994.

Dao, James. Once Destitute, Oneida Tribe Braces for Flood of Gambling Profits in New York Times, July 18, 1993.

Goodman, Robert. 1994. Legalized Gambling as a Strategy for Economic Development. University of Massachusetts, Amherst: Center for Economic Development.

Hopkins, Hohm Christian. The Next of the Mohegans

Judson, George. Weiker Signs Agreement with 2 Tribes on Casino Gambling in The New York Times, April 26, 1994

MacDonald, Bruce (editor). Congress, Tribes Debate Indian Gaming Law' Changes in Pequot Times, September, 1994

Nachison, Andrew. Deadw'ood's Gamble in Readers Digest, June 1994.

Popkin, James and Katia Hetter. America's Gambling Craze in U.S. News \& World Report, March 14, 1994.

Rivera, David. Safe Gamble: Foxwoods Jobs Halted Free-Fall (employment) in Norwich Bulletin, October 1994. 
Roush, Chris. So Much For the Puritan Heritage in Business Week, October 18, 1993.

Sternlieb, George and James Hughes. 1983. The Atlantic City Gamble. Massachusetts. Harvard University Press. 